\title{
Nepal: 2008 Article IV Consultation-Staff Report; Staff Supplement; Public Information Notice on the Executive Board Discussion; and Statement by the Executive Director for Nepal
}

Under Article IV of the IMF's Articles of Agreement, the IMF holds bilateral discussions with members, usually every year. In the context of the 2008 Article IV consultation with Nepal, the following documents have been released and are included in this package:

- $\quad$ The staff report for the 2008 Article IV consultation, prepared by a staff team of the IMF, following discussions that ended on March 14, 2008, with the officials of Nepal on economic developments and policies. Based on information available at the time of these discussions, the staff report was completed on May 2, 2008. The views expressed in the staff report are those of the staff team and do not necessarily reflect the views of the Executive Board of the IMF.

- A staff supplement on the joint IMF/World Bank Debt Sustainability Analysis.

- $\quad$ A Public Information Notice (PIN) summarizing the views of the Executive Board as expressed during its May 16, 2008 discussion of the staff report that concluded the Article IV consultation.

- $\quad$ A statement by the Executive Director for Nepal.

The document listed below has been or will be separately released.

Selected Issues Paper

The policy of publication of staff reports and other documents allows for the deletion of market-sensitive information.

\author{
Copies of this report are available to the public from \\ International Monetary Fund • Publication Services \\ $70019^{\text {th }}$ Street, N.W. $\bullet$ Washington, D.C. 20431 \\ Telephone: (202) 623-7430 • Telefax: (202) 623-7201 \\ E-mail: publications@imf.org • Internet: http://www.imf.org
}

Price: $\$ 18.00$ a copy

\section{International Monetary Fund Washington, D.C.}





\section{SSINTERNATIONAL MONETARY FUND}

\section{NEPAL}

\section{Staff Report for the 2008 Article IV Consultation}

Prepared by the Staff Representatives for the 2008 Consultation with Nepal

Approved by Kalpana Kochhar and Matthew Fisher

May 2, 2008

- This report is based on discussions held by the mission team in Kathmandu during March 1-14, 2008. The team comprised Messrs. Aitken (Head), D'Hoore, and Nyberg (all APD), and Mr. Peiris (MCM), with assistance from Mr. Pitt (Resident Representative). Mr. Warjiyo (OED) attended the concluding discussions.

- Counterparts: The team met with Minister of Finance Mahat, Acting Governor of the Nepal Rastra Bank Manandhar, and other senior officials.

- Fund relations: A PRGF arrangement (for an amount of SDR 49.9 million, 70 percent of quota) expired in November 2007 with the conclusion of the fifth review.

- Exchange rate: Nepal maintains a peg with the Indian rupee. Nepal has accepted the obligations of Article VIII, Sections 2, 3, and 4, and maintains an exchange system that is free of restrictions on the making of payments and transfers for current international transactions.

- Fund technical assistance: The Fund has an extensive program of TA to Nepal in the areas of revenue administration, central banking and bank supervision, and statistics.

- Statistical issues: Generally adequate for surveillance, with scope for improvement, in particular in the timeliness and coverage of fiscal data, and in balance of payments compilation of remittances, and official and private financial flows. 


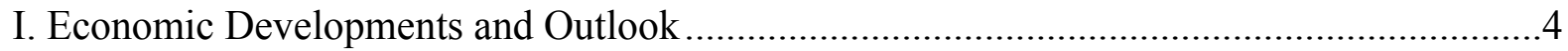

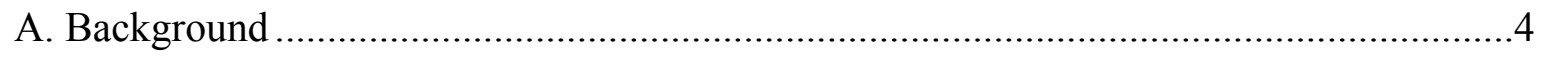

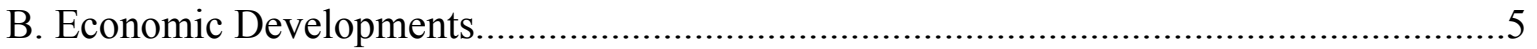

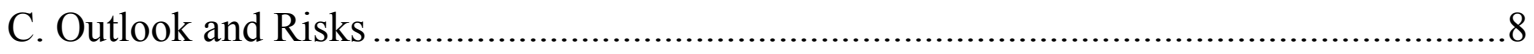

II. Policies to Promote External Stability .................................................................

A. Maintaining the Favorable Macroeconomic Environment …..................................8

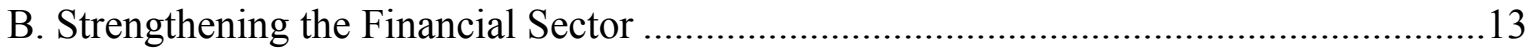

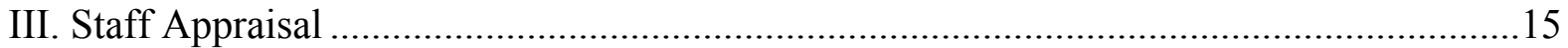

Boxes.

1. The Role of Remittances in Nepal's Balance of Payments ...........................................11

2. The State of Nepal's Financial Sector .............................................................................. 14

Figure

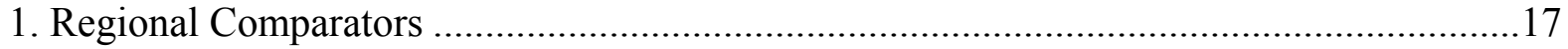

Tables

1. Selected Economic Indicators, 2003/04-2007/08 ......................................................... 18

2. Summary of Government Operations, 2006/07-2012/13 ................................................19

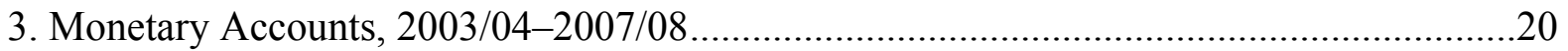

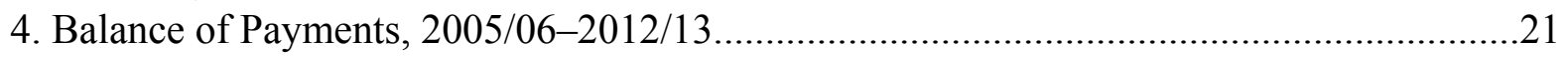

5. Medium-Term Macroeconomic Framework, 2004/05-2012/13 ….................................22 


\section{EXECUTIVE SUMMARY}

\section{Background}

- Despite a background of civil conflict and major political upheavals, macroeconomic performance over the past several years has been stable. Growth has been maintained albeit at low levels, inflation has remained stable, the budget stance has been cautious, and foreign exchange reserves are ample.

- However, progress on structural reforms has been held back by the fragile political environment. Vulnerabilities in the financial sector remain and could be growing, with rapid credit growth, loose monetary conditions, and weak central bank supervision persisting. The losses of the state oil company are mounting.

- Unsettled political circumstances pose the most immediate risk to macroeconomic stability and growth. Structural reform progress during the political transition will be slow and risks from the political situation will remain significant. The demands of the peace process could result in pressures for greater public spending. In this environment undertaking needed structural reforms and maintaining budget discipline will be challenging.

\section{Key Policy Issues}

- Budget discipline is a necessary condition for preserving macroeconomic stability. In balancing the need to increase spending in some areas while maintaining domestic borrowing at sustainable levels, further improvements in revenue collection are necessary. A key short-run priority is to limit and eventually eliminate the losses of the state oil company.

- Nepal's peg to the Indian rupee continues to be appropriate in the near term. While a widening productivity gap with India could present some challenges over time for exchange rate management, now would not be the right time to consider changing the rate or the regime.

- The authorities should take a more active role in reaching and maintaining a tighter monetary policy, as an overall bias toward excess liquidity has led to negative real interest rates, rapid credit growth, potentially destabilizing asset price increases, and some capital flight.

- $\quad$ Renewed impetus should be given to strengthening supervision and regulatory enforcement to maintain financial stability in the face of rapid banking sector growth. The legal framework is improving, but stronger efforts are needed in enforcement. The application of the stricter licensing requirements will be an important signal of the authorities' willingness to tighten enforcement going forward. 


\section{ECONOMIC DEVELOPMENTS AND OUTLOOK}

\section{A. Background}

1. Nepal is undergoing a major political transition. The end of the decade-long civil conflict in April 2006, the interim government takeover from the monarchy, and the comprehensive peace agreement between the government and the Maoist party in November 2006 set the stage for a transition to a new democratic governance structure.

2. The next step in this process, the writing of a new constitution, will be carried out by the Constituent Assembly. After several delays the elections to determine this assembly were held on April 10, 2008. Despite pre-election violence the elections themselves were considered by and large free and fair by international observers, and the results appear to be broadly accepted. While the final results are still not known, the Maoist party is emerging as the clear victor. A new government has yet to be formed and the policy agenda that will emerge is still uncertain.

\section{Despite recent progress, however, the political situation is highly fragile.}

Relations among major parties remain contentious. The situation in the Terai (the southern plains bordering India) remains tense as militants have increasingly agitated for more regional autonomy and a greater stake in national politics, and violence and strikes have been widespread. Given these obstacles there is a risk that the political transition will stall, with fundamental tensions remaining unresolved.

\section{Nepal's history of civil conflict, political instability, poor governance, and weak} structural reform has retarded economic growth. Per capita GDP in Nepal has barely risen in the last decade and the country remains one of the poorest in the world. Nepal has largely been left behind in the region's recent growth boom (Figure 1).
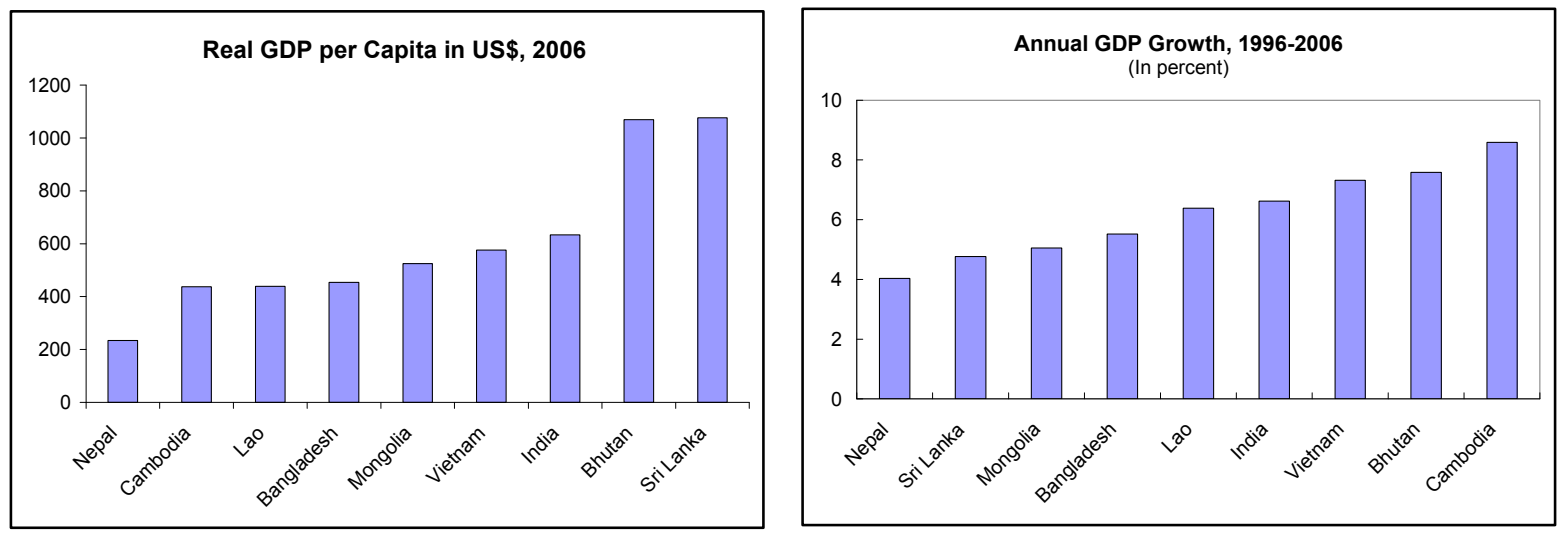


\section{B. Economic Developments}

5. Macroeconomic performance under the recent PRGF-supported program, which ended last November, has been stable (Tables 1-4). Despite a background of civil conflict and major political upheavals during the program period:

- Growth has been maintained, albeit at low levels - output growth has averaged 3 percent since 2002. However, domestic unrest has harmed private sector activity and created an unfavorable investment climate, keeping growth below the average of the last decade. Structural impediments including poor infrastructure, input supply disruptions, and unstable labor relations have also retarded

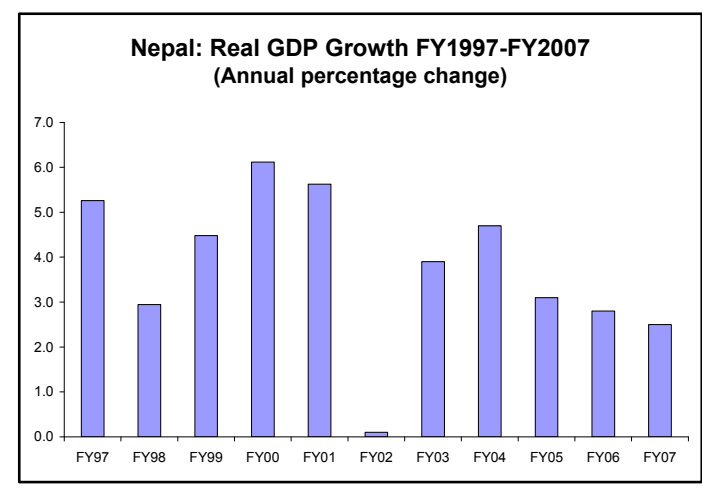
growth.

- Inflation has remained stable - the exchange rate peg to the Indian rupee has helped keep consumer price inflation below 8 percent during the program period. Asset prices, however, have shown signs of accelerating.

- The budget stance has been cautious - over the last several years domestic budget financing has been held to about 1-2 percent of GDP. Revenue growth has been strong,

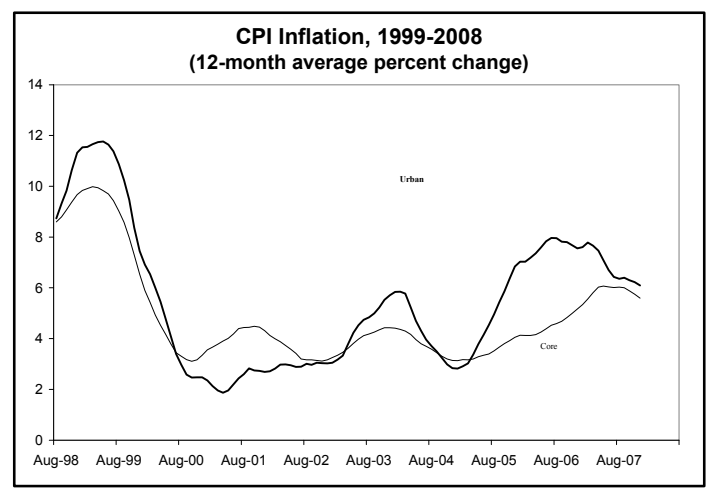
averaging 15 percent per year. Limited foreign borrowing and more recently the weakness of the U.S. dollar have reduced public debt to below 50 percent of GDP.
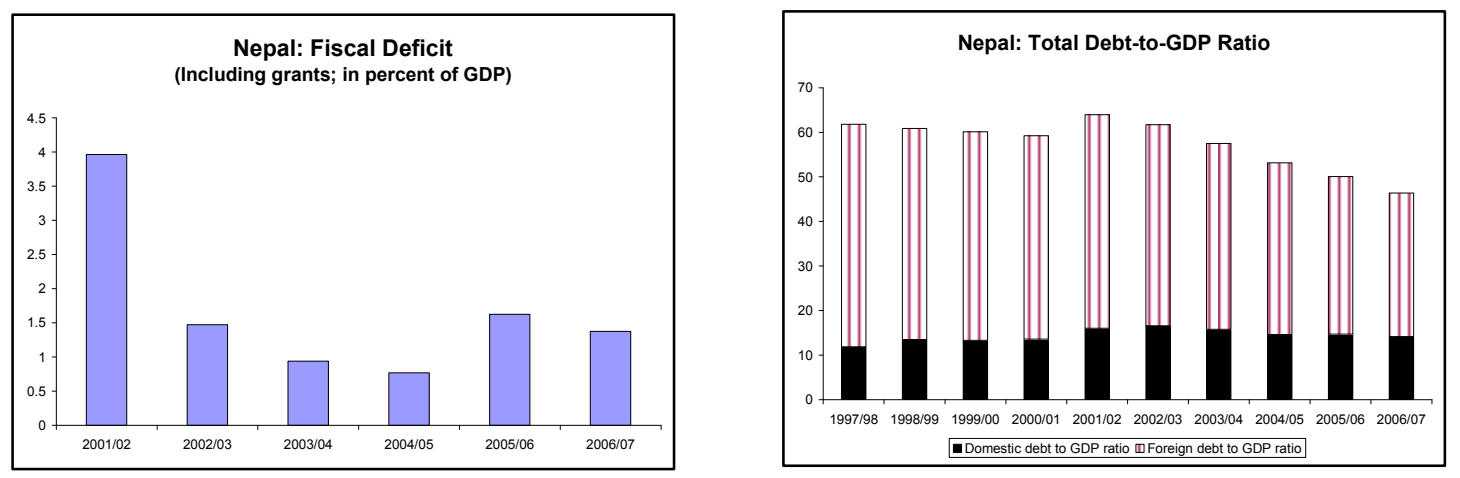

- Foreign exchange reserves are ample — reserves of the central bank have doubled since 2002 as the deteriorating trade deficit has been more than offset by growing remittances from overseas labor and to a lesser extent donor inflows. Although the rate of 
accumulation has recently slowed, reserves currently stand at \$2 billion, or 6 months of imports.

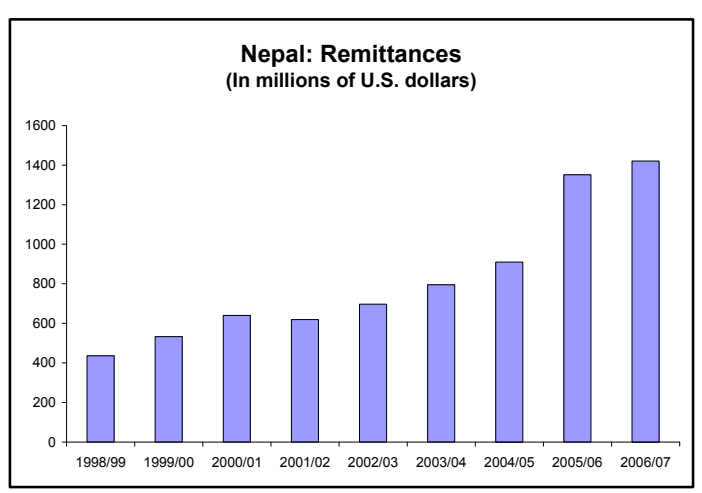

- $\quad$ The real exchange rate has appreciated by 20 percent over the last three years in large part driven by the decline in the dollar against the Indian rupee. With 70 percent of exports going to India, however, this measure may overstate the impact of the dollar's decline on Nepal's export competitiveness. $^{1}$

\section{The outlook for $\mathbf{2 0 0 7 / 0 8}$ remains}

stable. The agricultural recovery, favorable service sector performance, and a significant increase in tourist arrivals could boost real GDP growth to $3 \frac{1}{2}-4$ percent in $2007 / 08$. The authorities were somewhat more optimistic, arguing that growth could reach $4 \frac{1}{2}$ percent. Anchored by the exchange rate peg, inflation is projected to remain broadly stable around $6 \frac{1}{2}$ percent to 7 percent, although higher food prices and any adjustments to the administered prices of fuel could add upward pressure. On the external side, rising oil imports and stagnant exports have led to a further deterioration in the trade deficit, but this will be more than offset by workers' remittances, which are expected to grow by 20 percent over last year.

7. While the macroeconomic performance has been stable, progress on structural reforms has been held back by the fragile political circumstances. In particular, little progress has been made to address institutional weaknesses in the financial sector and in public financial management.

\footnotetext{
${ }^{1}$ The measured real effective exchange rate uses trade weights which understate the current share of Nepal's trade with India.
} 
8. Vulnerabilities in Nepal's financial sector remain, and could be growing.

- Loose monetary conditions have led to negative real interest rates, rapid and potentially destabilizing stock market and property price increases, and some capital flight to India seeking higher returns. Credit growth has been high, with aggressive lending by many banks pushing their creditto-deposit ratios to levels above 100 percent.

- Supervisory capability and regulatory

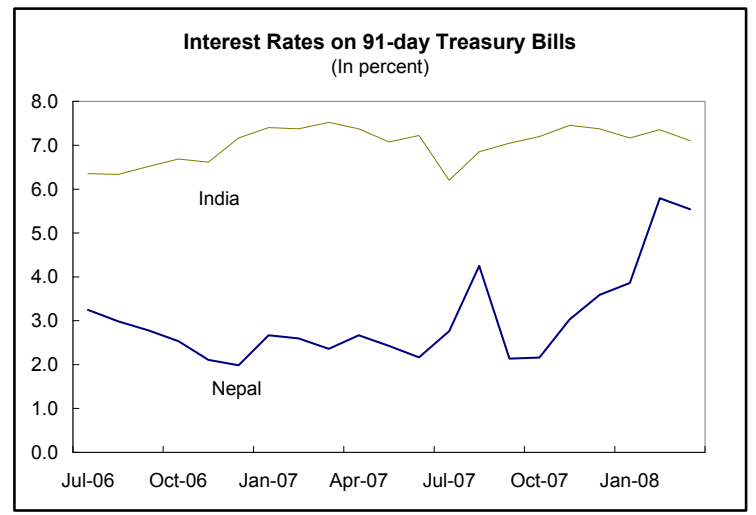
compliance remain weak. In recent years the legal framework for supervision has been overhauled, but enforcement within this framework remains a concern-decision making is slow and there has been significant and visible supervisory forbearance. Efforts to collect sizeable overdue loans from willful defaulters have yielded few results. A stricter licensing policy approved in April 2007 has been undermined by the recent proliferation of licenses granted to banking institutions whose applications had been submitted under the old licensing regime.

- Reforms of the two large public banks have stalled. With World Bank help, progress has been made in placing their lending on a more commercial basis, operations have been restructured and modernized, and losses have been reduced or eliminated. However, the banks are still insolvent and the lack of a clear strategy on how to move forward prevents the gains of reform from becoming permanent.

\section{Limited progress has been made in addressing Nepal's structural weaknesses in} tax administration and public financial management. Overall, the accounting, auditing, and reporting of public sector operations are inadequate. The budget coverage is confined to only the central budget with no information on quasi-fiscal activities, internal control procedures are not fully effective, and the management of spending is weak. Specifically:

- While impressive progress has been made on improving tax administration through the operations of the Large Taxpayer Office, reforms are needed to modernize customs, a significant source of revenue in Nepal.

- Around one-third of government expenditure takes place outside the budget framework in extrabudgetary funds and autonomous bodies, in part to channel spending by donors lacking trust in the transparency and accountability of the central government budget.

10. Public enterprises, and the Nepal Oil Corporation in particular, pursue quasifiscal activities involving significant subsidies. At current crude prices, the oil company is 
running an annualized deficit of about $1 \frac{1}{2}$ percent to 2 percent of GDP. In general the accountability and transparency of public enterprises are weak.

\section{Outlook and Risks}

\section{Nepal's growth prospects depend most importantly on a peaceful political} transition. Steady but low growth could continue in the near term. However, insecurity, violence in the Terai region, input supply disruptions, and structural barriers continue to discourage investment, limit exports, and hamper transition to a higher growth path. With Nepal located between two of the fastest growing economies in the world, an easing of these constraints, steady progress on the political front, and the development of Nepal's vast untapped hydropower resources could lift growth to levels of 5-51/2 percent over the medium term (Table 5).

\section{The unsettled political environment poses the most immediate risk to} macroeconomic stability and growth. Structural reform progress during the political transition will be slow, and political risks will remain significant, even if the results of the constituent assembly elections are broadly accepted. The demands of the peace process - a sense of entitlement among stakeholder groups, and the call to address the grievances built up over decades, particularly for the underdeveloped and politically underrepresented population of the Terai - could result in pressures for greater public spending. In this environment undertaking needed structural reforms and maintaining budget discipline will be challenging.

\section{Policies to Promote External Stability}

In the last several years the government's policies under the PRGF-supported program, in particular fiscal restraint and the peg to the Indian rupee, have been critical in supporting macroeconomic stability and growth despite political turmoil and civil conflict. The authorities agreed that now that the program has expired, relaxing these policies would undermine the prospects for economic recovery at a critical point in the political transition.

\section{A. Maintaining the Favorable Macroeconomic Environment}

\section{Fiscal Policy}

\section{The authorities recognized the critical role that maintaining budget discipline} will play in preserving macroeconomic stability. It is essential to support the robustness of the pegged exchange rate regime and maintain Nepal's debt-to-GDP ratio on a declining path from still high levels. ${ }^{2}$ Budget discipline is also needed as a safeguard against a slowdown in

\footnotetext{
${ }^{2}$ The debt dynamics in the revised DSA are broadly consistent with those of the previous assessment in 2007 (Appendix I, Country Report No. 07/204). At the same time the initial net present value of debt has fallen slightly with the appreciation of the Nepalese rupee and lower-than-projected loan disbursements in the interim.
} 
revenue growth, or if higher unforeseen expenditures become necessary to absorb losses by public enterprises or to address the financial weaknesses of the public banks.

\section{Despite the strong revenue performance, Nepal's budget deficit could rise this} year to about 3 $1 \frac{1}{2}$ percent of GDP, reflecting in part the one-off costs of the elections and the clearance of most of the Nepal Oil Corporation's arrears. While these additional costs can be absorbed this year, the authorities agreed that this is not a sustainable fiscal policy position going forward. Excessive reliance on domestic financing could ultimately threaten budget solvency as a growing interest bill generates additional fiscal pressure. For this reason, the authorities aim to limit domestic borrowing in the next budget to a more sustainable level of 1-2 percent of GDP.

\section{Further improvement in revenue collection is essential in ensuring the} sustainability of the budget. Staff recognize that in planning the next budget, there may be a need to increase spending in some areas to improve the provision of public goods and address the legacy of the civil conflict. Given this, staff urged that the impressive progress achieved by the Large Taxpayer Office with the help of FAD technical assistance be broadened to other areas of revenue administration. On the spending side, the focus should be on allowing needed increases in post-conflict and infrastructure spending, particularly where donor financing is available, while keeping recurrent spending at sustainable levels.

\section{The key short-run priority is to limit and eventually eliminate the losses of the} state oil company, a frequent and, at times, large drain on the budget. The setting of prices of petroleum products remains highly politicized. As a result, the government's ability to address the company's losses through ad hoc price increases has been limited, and the piecemeal approach taken so far has disrupted supplies for extended periods. There is broad agreement within the government that the current situation is not sustainable and the authorities were hopeful that price adjustments could be made as soon as political conditions permit following the elections. The staff argued that a permanent solution is required, with the preferred option being the introduction of an automatic pricing mechanism to bring about a phased convergence in domestic prices to world levels in a depoliticized manner. In the meantime, the staff urged that all the company's flow losses be covered by the budget in a timely and transparent manner and any lending to the company for this purpose be reflected in public debt.

\section{The staff encouraged the authorities to accelerate reforms aimed at increasing} accountability, transparency, and credibility of public expenditure. Through Fund and donor technical assistance, a range of measures have been proposed to improve the coverage

In view of the improved debt indicators, Nepal's external debt dynamics are now technically assessed to be subject to a moderate risk of debt distress. This is a change from the previous DSA which classified Nepal as at high risk of debt distress. 
of financial information and the accounting system which would strengthen the government's ability to conduct fiscal policy, monitor expenditure, and coordinate donor activity. The authorities agreed on several areas where further technical assistance would be particularly useful, including developing a chart of accounts and laying the groundwork for establishing a treasury single account.

\section{Monetary Policy and the Exchange Rate}

18. The exchange rate peg to the Indian rupee has been instrumental in anchoring inflation over the last several years. This arrangement, in place since 1993, has served Nepal well given close and increasing economic integration between the two countries.

19. In assessing whether the current level of Nepal's peg remains appropriate, analysis must extend beyond the narrow trade balance. The merchandise trade deficit is large and has clearly trended upward over the last several years. However, a major factor driving balance of payments developments is workers' remittances inflows, which at over $\$ 1 \frac{1}{2}$ billion are more important than exports as a source of foreign exchange. Since most of these inflows support consumption - a large part of which is imported - the weakening trade balance cannot be separated from growing remittance inflows. Unlike donor flows or other transfers, remittances are transfers that in effect represent an export of labor services. Indeed, the trade balance combined with remittances is much more stable than the merchandise trade balance

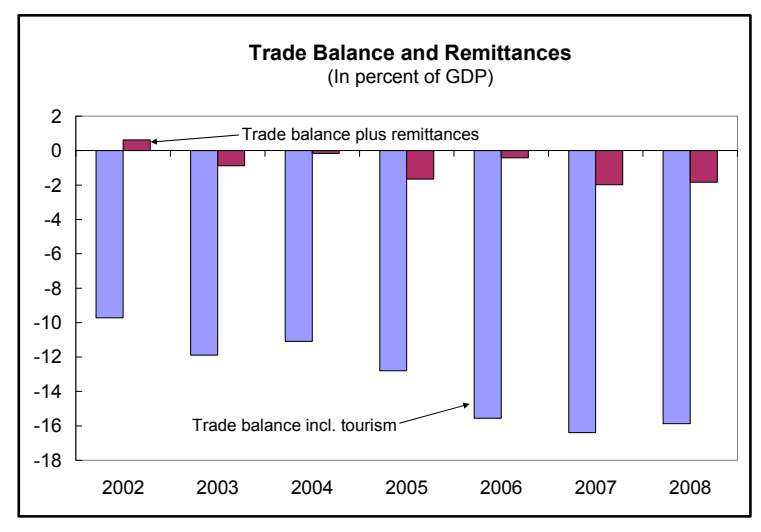
alone. While the supply and demand factors driving remittances are in many cases different from merchandise exports, excluding remittances and focusing only on the trade balance would be misleading in any analysis of the appropriate level of the exchange rate (Box 1).

\section{Taking the balance of payments as a whole, the current level of the exchange} rate appears broadly consistent with its equilibrium level. The overall external balance has been and remains in surplus, with the trade deficit largely offset by remittance inflows. Remittances are likely to persist, and will continue to provide a large sustainable source of inflows to the balance of payments. In terms of the underlying savings-investment balance, a country at Nepal's level of development should be running a modest current account deficit 


\section{Box 1. The Role of Remittances in Nepal's Balance of Payments}

Nepal's persistent balance of payments surplus is a key factor in assessing whether the exchange rate is near equilibrium. The balance of payments has been in surplus for the last decade, with an annual reserve accumulation of around $\$ 150$ million over the last five years. This surplus continues despite the deteriorating trade balance, primarily owing to Nepal's unique role as a major exporter of labor services. Remittances from workers' earnings abroad have been a dominant flow of foreign exchange, with annual flows now exceeding 15 percent of GDP.

\section{Remittances are an integral part of the Nepalese} economy, driven by a number of relatively durable supply and demand factors. On the supply side, persistent violence in the Terai region has suppressed employment opportunities, driving workers to seek labor income abroad - migration across the relatively porous border with India has been longstanding, with about one million Nepalese currently estimated to be working there.

Increasingly however, demand for Nepalese workers is being fueled by large infrastructure

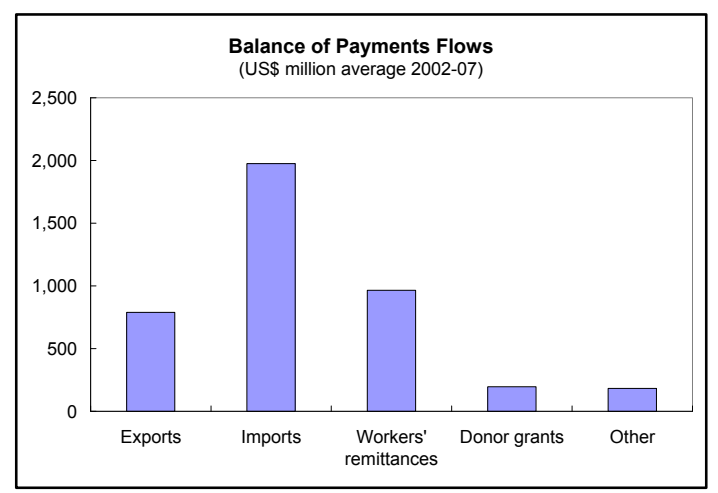
programs in oil-rich Persian Gulf states, as well as in several Asian countries. These workers tend to earn significantly higher wages than in India.

Remittances have played a major role in boosting Nepal's imports. Although higher world oil prices have contributed somewhat, the main factor behind rapid import growth in recent years has been higher consumption as remittances raise disposable income and demand for durable goods.

At the same time exports have experienced a number of shocks. While exports to India have overall been stable (and account for about 70 percent of total exports), the growth rate of exports to other destinations has fallen. Driving this has been the decline in the textiles industry, the main Nepalese export to countries other than India. This industry has faced persistent unrest in the Terai, electricity supply shortages, poor labor relations, campaigns against child labor, and the expiration of the multi-fiber agreement in 2005.

On balance, however, growth in remittances has consistently produced balance of payments surpluses. Nepalese workers finding employment abroad has been a fortunate development given the problems facing the domestic economy-indeed, the World Bank estimates that remittances have been the main factor behind Nepal's declining poverty rate over the last decade. But employment abroad is also likely to have significant social costs, and is not contributing to Nepal's long-term development. Bringing production to within Nepal's borders will require establishing political stability, reducing civil unrest, and resolving the country's structural problems. 
financed by official grants and loans, which it is at present. ${ }^{3}$ Under these circumstances, attempts to offset the recent real appreciation through a step devaluation are unlikely to be effective, and could be quickly eroded by a period of higher inflation both from direct passthrough effects and indirectly as inflows enter the economy adding to already high domestic liquidity.

\section{Regarding the exchange rate regime, maintaining the peg to the Indian rupee would continue to be appropriate for Nepal's macroeconomic stability and development in the near term.}

- There are obvious advantages of the pegged regime. It provides a highly credible and simple nominal anchor by importing macroeconomic policy discipline from India, particularly important in a country like Nepal with limited central bank independence and weak institutions. Pegging to the Indian rupee is the natural choice given the extensive and growing commercial ties with India, keeping business uncertainty and transactions costs low and promoting integration with one of the world's fastest growing economies.

- At the same time, the advantages of a floating regime are fairly limited in Nepal at present. While it gives some monetary policy autonomy and flexibility in responding to external shocks, a successful floating rate regime has extensive institutional and operational requirements. The NRB is a long way from having the independence and discipline to conduct policy using an alternative anchor and successfully keep inflation low. The process of building the NRB's credibility would be very costly in the current economic circumstances, and without a very strong political mandate, would not succeed.

\section{While the regime remains appropriate at present, maintaining the peg could} present some challenges over time if productivity in India continues to grow more rapidly than in Nepal. The peg would provide clear benefits in terms of fostering integration with a rapidly growing economy, but it would also require domestic factor markets to be sufficiently flexible to allow the real exchange rate to adjust at a different pace than India. Until now this has largely been the case, particularly through labor mobility, but going forward the productivity differential is expected to grow. In these circumstances, other more flexible regimes, including a basket peg, could help smooth domestic adjustment to a possible further appreciation of the Indian rupee.

23. Staff discussed these challenges with the authorities. The authorities agreed with the staff's assessment of the implications of higher productivity growth in India, but

\footnotetext{
${ }^{3}$ For a country like Nepal, assessing an "equilibrium" exchange rate presents considerable challenges. Data quality is poor, the political and security situation is evolving rapidly, and donor flows are uneven. The unusually important role of remittances complicates comparisons with other countries. In these circumstances, and as in many low-income countries, a more mechanical econometric approach would yield little information about the appropriate level of the exchange rate level.
} 
underscored that they are currently not considering any alternatives to the existing pegged arrangement, arguing that any marginal benefits of a move away from the peg were outweighed by the costs of a regime change in the prevailing political and economic environment. Moreover, they maintained that the simplicity, predictability, and transparency of the current peg will continue to be a critical anchor for the economy in the period ahead, and feared that a move to a basket-like arrangement would add uncertainty and fuel speculation. They emphasized that the current regime, by allowing for changes in the parity when needed, would be robust to future external shocks. Staff agreed with the authorities' assessment that although the regime could face challenges in the future, now would not be the right time to change the rate or the regime.

\section{The staff argued that there is a clear need to tighten monetary conditions. A} relatively passive monetary policy has allowed foreseeable exogenous events, such as changes in government spending, to lead to potentially disruptive swings in liquidity conditions, with an overall bias toward excess liquidity and negative real interest rates. Loose monetary conditions have fueled a credit and asset price boom, and some capital flight. The staff encouraged the authorities to take an active role in reaching and maintaining a tighter monetary policy. Better liquidity management and forecasting is needed, and will require foremost a separation of the formulation and execution of monetary policy from public debt management. The staff argued that the temporary credit squeeze in January underscored this need, and illustrated how the highly uneven distribution of liquidity among banks could undermine monetary policy, particularly with a relatively shallow interbank credit market. The authorities agreed in principle that monetary conditions could be tightened, and the NRB has the tools to do so, including through the increased use of open market operations.

\section{B. Strengthening the Financial Sector}

\section{Nepal's fast growing financial sector presents a challenge to financial stability in} the near term and beyond. Some of the growth in the banking sector is expected and reflects a natural deepening of the financial system in Nepal. However, the rapid proliferation of financial institutions and credit growth has coincided with a sharp rise in stock market and property prices, and adds to the already large regulatory burden of the NRB (Box 2).

\section{To address this, staff urged the authorities to give renewed impetus to recent} efforts to strengthen supervision and regulatory enforcement. Much depends on the enforcement efforts backing the Banking and Financial Institutions Act once this Act is approved by parliament, which in principle should improve the legal framework for supervision and bank consolidation. High and rising credit-to-deposit ratios, weak loan classification standards, and poor asset quality at some banks call for greater vigilance on the part of supervisors. Staff urged action against those private banks which continue to operate 


\section{Box 2. The State of Nepal's Financial Sector}

Nepal's financial system is underdeveloped but sizeable relative to countries in the region. The total assets of the banking system to GDP stood at 81 percent in July $2007 .{ }^{1}$ Public banks account for about one third of banking sector assets. The Nepal stock market has historically played only a marginal role, although the doubling of the stock price index between end 2006 and 2007 has increased market capitalization ( 90 percent of which is accounted for by banking institutions).

The banking sector is characterized by a large and growing number of deposit-taking institutions. The

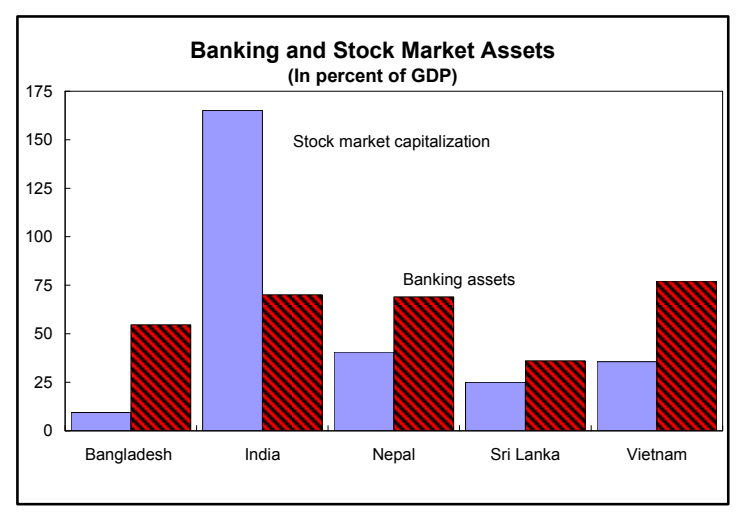
numbers of licensed commercial banks increased from 17 to 23 in the last three years. There has also been a rapid proliferation of the number of deposit-taking nonbank financial institutions, nearly doubling in 2007 to 139 institutions.

The increase in institutions has been accompanied by rapid credit growth, currently around 25 percent. Lending by private commercial banks is particularly rapid at 36 percent, corresponding to a decline in lending growth by the two main state-owned commercial banks. While some of the lending growth reflects a natural deepening of the financial system, loose monetary conditions, competitive pressures, and intermediation of worker remittances to housing and consumer credit have also played a role. While the overall NPL ratio has been declining, this is a lagging indicator of asset quality, and the impact of the recent increase in lending growth on the health of banks' balance sheets is not yet known. High exposure to single borrowers remains a concern.

Credit growth is increasingly driven by the aggressive lending behavior of many smaller banking institutions. System-wide, the average credit-to-deposit (CD) ratio for the banking system has increased from 60 percent over 2000-2006 to 78 percent by end-2007. Nearly 25 percent of banking assets are now held by smaller private banks with $\mathrm{CD}$ ratios exceeding 90 percent - very high by international standards. Although system-wide liquidity is adequate, the shallowness of the interbank market prevents a redistribution of liquidity to highly leveraged banks when shortages occur, forcing the NRB to inject liquidity through its standing liquidity facility and complicating monetary policy management.

While banks' direct exposure to the real estate and

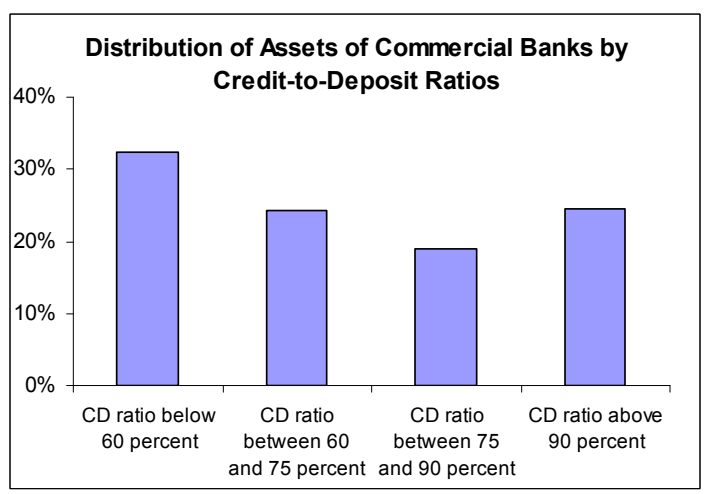
stock market is modest, the indirect exposure could be quite large. Nearly 60 percent of bank loans are secured by real estate assets, making banks vulnerable to a sharp drop in real estate prices. In contrast to international practice, Nepalese banks can lend against stocks as collateral. While this lending remains small (about 3 percent of the loan portfolio of banks), its recent growth, likely backing additional stock purchases, is regarded as a key factor behind the recent stock market boom.

${ }^{1}$ The banking sector includes commercial banks, which account for 84 percent of total financial assets, development banks, and deposit-taking financial institutions. 
despite violating capital adequacy requirements to prevent them from undermining the credibility of the regulatory framework. Staff also stressed that particular attention should be paid to compliance with single-borrower limits, and to assessing and monitoring the financial sector's indirect exposure to the property and stock markets. In this regard, the staff welcomed the recent NRB directive to restrict margin lending by banking institutions using stocks as collateral. The application of the stricter licensing requirements approved in April 2007, in particular the "fit and proper" test, will be a signal of the authorities' willingness to enforce the new regime going forward. The mission noted the NRB's progress in moving toward risk-based supervision and implementing Basel II beginning July 2008, and encouraged further efforts to this end.

27. In addition, staff encouraged the authorities to adopt a clear strategy for completing the process of commercializing the two large public banks. Although most of the politically-motivated lending appears, for the moment, to have been limited under new management teams, a strategy is needed for bringing these banks to solvency and ensuring that they will operate on a commercial basis going forward. The authorities agreed with this assessment, but observed that there is currently no political consensus on how to resolve these banks, either through privatization or other methods. They hoped a new effort to address these issues would emerge sometime after the April elections.

28. Finally, staff expressed concern that lack of progress on debt collection could be seen as signaling a lack of will to enforce existing regulations. While the debts of the willful defaulters do not represent a systemic risk, staff urged ongoing government action, including through the Debt Recovery Tribunal, to shore up the credibility of the regulatory regime.

\section{StAfF Appraisal}

29. Over the past several years Nepal has maintained moderate inflation and budget discipline. Although output growth has been low, the preservation of macroeconomic stability despite the civil conflict and major political upheavals is a remarkable achievement for which the government deserves much credit.

30. Nepal is now at a critical juncture, and continued stability is a key condition for allowing the political transformation currently taking place to result in higher, broadbased economic growth. In addition to addressing structural impediments such as poor infrastructure and input supply disruptions, a prerequisite for higher growth will be maintaining budget discipline and ensuring the soundness of the banking sector during the challenging period ahead.

31. Maintaining budget discipline is a necessary condition for preserving macroeconomic stability. In balancing the need to increase spending in some areas to improve the provision of public goods and address the legacy of the civil conflict while 
maintaining domestic borrowing at sustainable levels, further improvement in revenue collection will remain a priority.

32. A key short-run priority is to limit and eventually eliminate the losses of the Nepal Oil Corporation. The introduction of an automatic pricing mechanism for petroleum products to ensure the depoliticization of pricing is the preferred permanent solution. Going forward, all the company's flow losses should be covered by the budget in a transparent manner.

33. Nepal's peg to the Indian rupee has served the country well, and maintaining this arrangement would continue to be appropriate in the near term for Nepal's macroeconomic stability and development. With the overall balance in surplus and the reserve position strong and stable, there appears to be little sign of misalignment at present. The peg provides a highly credible, simple, and predictable nominal anchor, and is a natural choice given the extensive commercial ties with India. While a widening productivity gap with India could present some challenges over time for exchange rate management, now would not be the right time to consider changing the rate or the regime.

34. The authorities should take a more active role in reaching and maintaining a tighter monetary policy, as an overall bias toward excess liquidity has led to negative real interest rates, rapid credit growth, potentially destabilizing asset price increases, and some capital flight. Better liquidity management and forecasting is needed, and will require separation of the formulation and execution of monetary policy from public debt management.

35. Renewed impetus should be given to strengthening supervision and regulatory enforcement to maintain financial stability in the face of rapid banking sector growth. Parliament approval of the Banking and Financial Institutions Act should further strengthen the regulatory framework, but significant improvements are needed in enforcement. The application of the stricter licensing requirements will be an important signal of the authorities' willingness to tighten enforcement going forward.

36. A clear strategy is needed for completing the process of commercializing the two large public banks. Although progress has been made under new management teams in restructuring these banks, a strategy is needed for bringing them to solvency and ensuring that they will be operated on a commercial basis going forward.

37. It is recommended that the next Article IV consultation take place on the 12-month cycle. 
Figure 1. Nepal: Regional Comparators

(Average 2003-07)
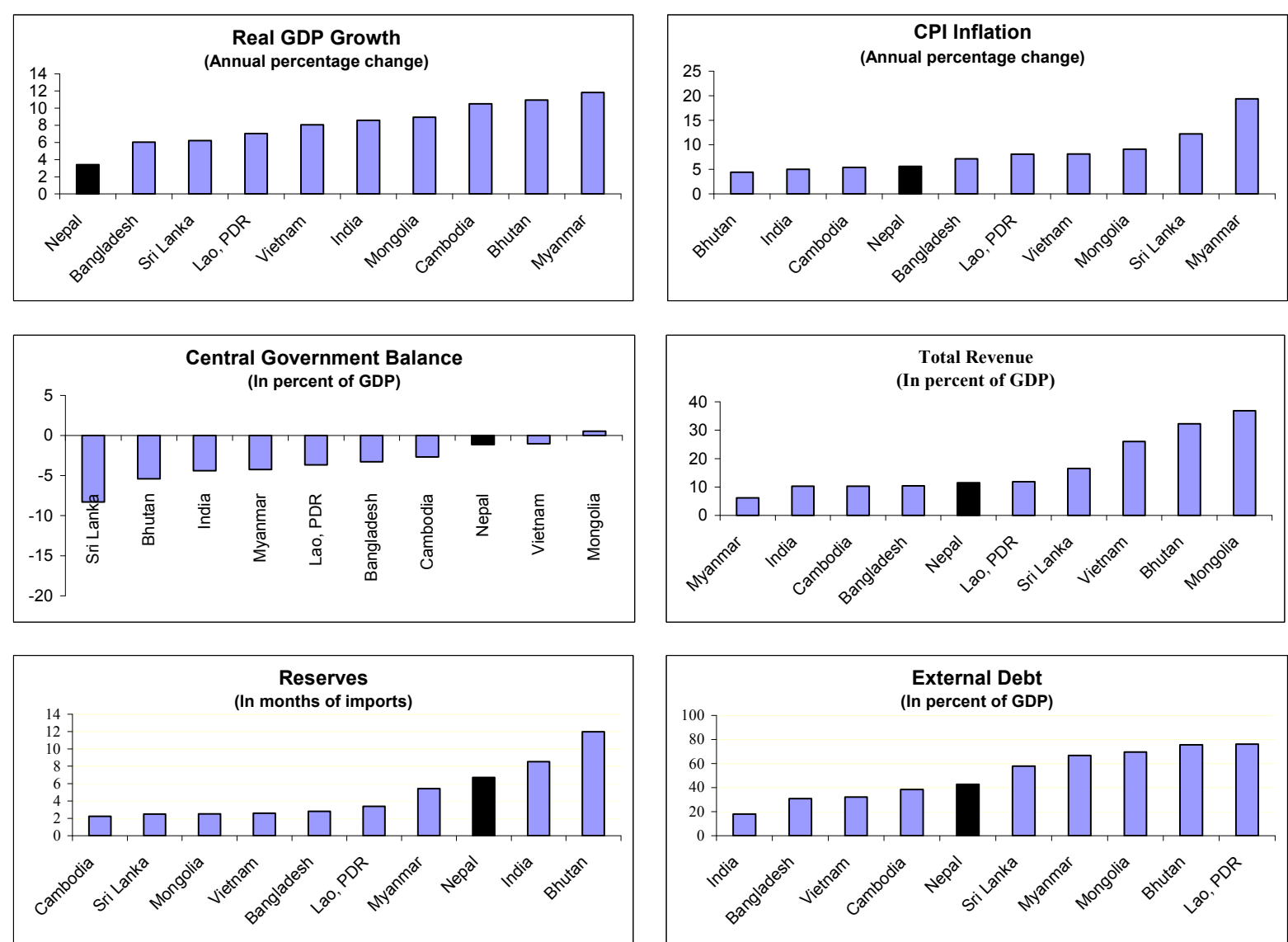

Sources: WEO, World Development Indicators, and various Fund Staff Reports. 
Table 1. Nepal: Selected Economic Indicators, 2003/04-2007/08 1/

\begin{tabular}{|c|c|c|c|c|c|}
\hline & $2003 / 04$ & $2004 / 05$ & $\frac{2005 / 06}{\text { Est. }}$ & $\frac{2006 / 07}{\text { Est. }}$ & $\frac{2007 / 08}{\text { Proj. }}$ \\
\hline & \multicolumn{5}{|c|}{ (Percent change) } \\
\hline Real GDP at market prices & 4.7 & 3.1 & 2.8 & 2.5 & 3.8 \\
\hline CPI (12-month change) & 2.0 & 6.6 & 8.3 & 5.1 & 7.0 \\
\hline $\mathrm{CPI}$ (period average) & 4.0 & 4.5 & 8.0 & 6.4 & 6.5 \\
\hline Fiscal indicators & \multicolumn{5}{|c|}{ (In percent of GDP) } \\
\hline Total revenue & 11.3 & 11.7 & 10.9 & 12.0 & 13.5 \\
\hline Total expenditure & 14.3 & 14.9 & 14.7 & 15.7 & 19.7 \\
\hline Current expenditure & 10.3 & 10.5 & 10.4 & 10.6 & 13.4 \\
\hline Capital expenditure and net lending & 4.0 & 4.4 & 4.3 & 5.1 & 6.4 \\
\hline Overall deficit before grants & 3.0 & 3.2 & 3.8 & 3.6 & 6.2 \\
\hline Overall deficit after grants & 0.9 & 0.8 & 1.6 & 1.4 & 3.6 \\
\hline Domestic financing (net) & 0.6 & 0.2 & 1.4 & 0.9 & 2.7 \\
\hline Public debt & 59.8 & 53.9 & 51.1 & 46.7 & 44.6 \\
\hline Money and credit & \multicolumn{5}{|c|}{ (Percent change, end-of-period) } \\
\hline Broad money & 12.8 & 8.3 & 15.4 & 14.0 & 18.0 \\
\hline Domestic credit & 9.8 & 13.9 & 16.3 & 12.0 & 20.3 \\
\hline Private sector credit $2 /$ & 14.2 & 12.9 & 17.8 & 12.1 & 18.3 \\
\hline Velocity & 1.9 & 2.0 & 1.9 & 1.8 & 1.7 \\
\hline Interest rates & \multicolumn{5}{|c|}{ (In percent) } \\
\hline 91-day treasury bill (end-of-period) 3/ & 1.5 & 3.9 & 3.3 & 2.8 & $\ldots$ \\
\hline Central bank refinancing $3 /$ & $2-51 / 2$ & $1 \frac{1}{2}-5 \frac{1}{2}$ & $1 \frac{11 / 2-61 / 4}{1}$ & $1 \frac{1}{2}-6 \frac{1 / 4}{4}$ & $\ldots$ \\
\hline Loans to industry $3 /$ & $81 / 2-13 \frac{1}{2}$ & $81 / 4-13 \frac{1}{2}$ & $8-13 \frac{1}{2}$ & $8-13 \frac{1}{2}$ & $\ldots$ \\
\hline Balance of payments & \multicolumn{5}{|c|}{ (In millions of U.S. dollars) } \\
\hline Current account balance (excluding official transfers) & 59 & -19 & 53 & -146 & -156 \\
\hline In percent of GDP & 0.8 & -0.2 & 0.6 & -1.4 & -1.3 \\
\hline Trade balance & $-1,053$ & $-1,190$ & $-1,521$ & $-1,761$ & $-2,074$ \\
\hline In percent of GDP & -14.5 & -14.6 & -17.0 & -17.2 & -17.1 \\
\hline Gross official reserves (end-of-period) & 1,457 & 1,501 & 1,797 & 2,008 & 2,027 \\
\hline In months of imports of goods and services & 7.3 & 6.4 & 6.7 & 6.5 & 5.8 \\
\hline Export value growth 3 / & 14.7 & 11.2 & 2.2 & 4.9 & 6.9 \\
\hline Import value growth & 15.8 & 12.2 & 17.3 & 11.9 & 14.1 \\
\hline External debt/GDP (in percent) 4/ & 46.1 & 39.9 & 39.1 & 32.6 & 29.1 \\
\hline Debt service (in percent) $5 /$ & 4.5 & 4.5 & 4.0 & 4.0 & 3.9 \\
\hline Exchange rate (Nrs./U.S. dollar, end-of-period) & 74.5 & 70.7 & 74.4 & 65.2 & $\ldots$ \\
\hline REER (end-of-period; percent change; negative = depreciation) & -2.2 & 7.0 & 1.4 & 10.7 & $\ldots$ \\
\hline NEER (end-of-period; percent change) & 0.1 & 3.3 & -2.9 & 8.3 & $\ldots$ \\
\hline Nominal GDP at market prices (Nrs. billions) & 536.7 & 589.4 & 646.5 & 719.5 & 795.2 \\
\hline
\end{tabular}

Sources: Data provided by the Nepalese authorities; and Fund staff estimates and projections.

1/ Fiscal year begins mid-July.

2/ Includes lending by the Agriculture Development Bank of Nepal (ABDN) since July 2006. Reflects loan write-off of Nrs. 16 billion during July to December 2006.

$3 /$ Excluding re-exports.

4/ Includes estimated short-term trade credits.

5/ In percent of exports of goods, services, and private transfers and income receipts; including debt service to the Fund. 
Table 2. Nepal: Summary of Government Operations, 2006/07-2012/13 1/

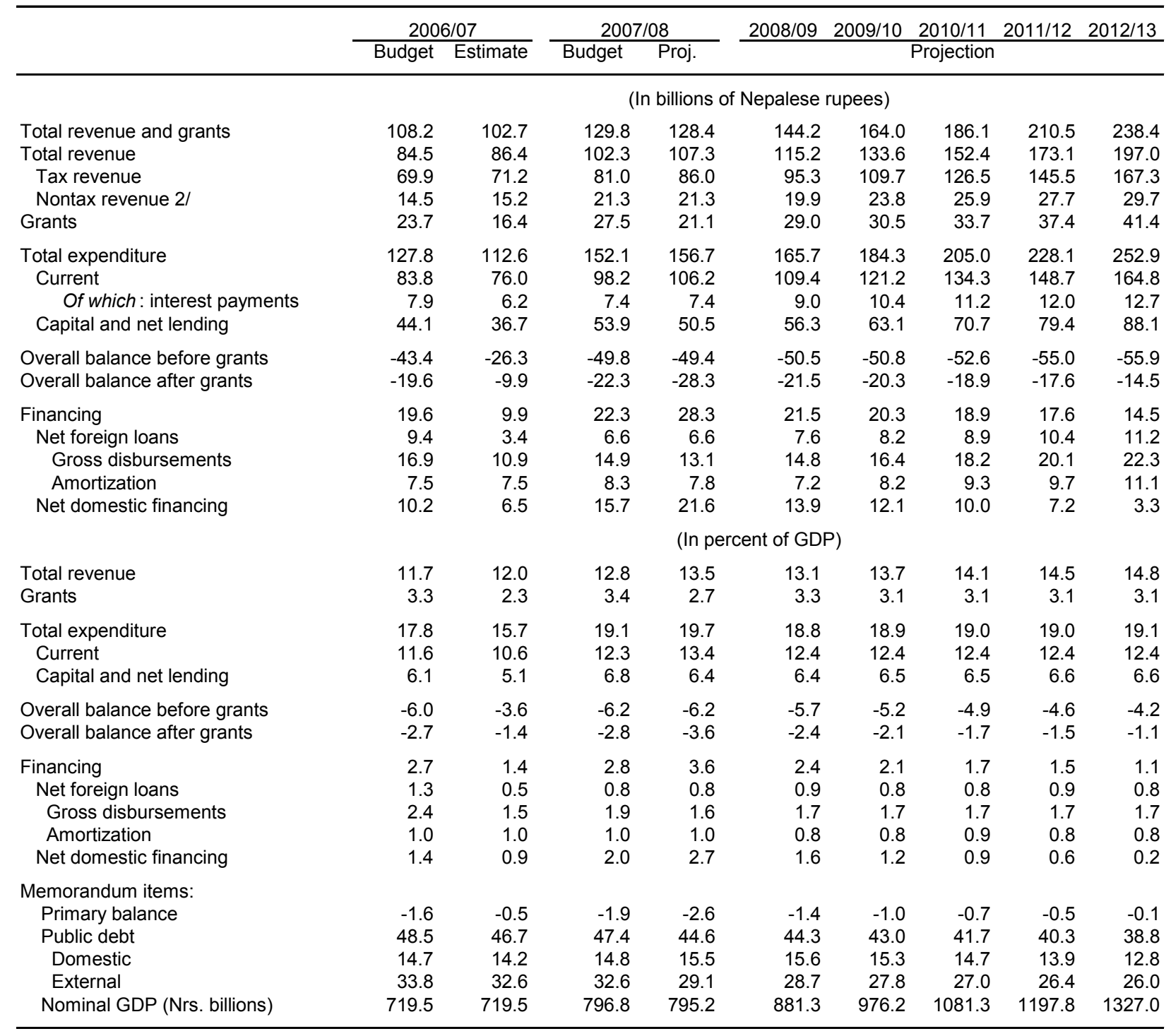

Sources: Data provided by the Nepalese authorities; and Fund staff estimates and projections.

1/ Fiscal years start mid-July. Table confined to central government operations as contained in the budget. 2/ Includes privatization receipts. 
Table 3. Nepal: Monetary Accounts, 2003/04-2007/08

\begin{tabular}{|c|c|c|c|c|c|}
\hline & $\frac{2003 / 04}{\text { Jul. }}$ & $\frac{2004 / 05}{\text { Jul. }}$ & $\frac{2005 / 06}{\text { Jul. }}$ & $\begin{array}{r}2006 / 07 \\
\text { Jul. }\end{array}$ & $\begin{array}{r}2007 / 08 \\
\text { Jul. } \\
\text { Proj. }\end{array}$ \\
\hline Monetary authorities & \multicolumn{5}{|c|}{ (In billions of Nepalese rupees) } \\
\hline Reserve money & 94.4 & 96.5 & 110.7 & 119.3 & 134.3 \\
\hline Net foreign assets & 108.2 & 103.9 & 131.6 & 126.3 & 127.9 \\
\hline \multirow[t]{2}{*}{ Net domestic assets } & -13.8 & -7.3 & -20.8 & -6.9 & 6.4 \\
\hline & \multicolumn{5}{|c|}{ (Change in percent of reserve money at start of period) } \\
\hline Reserve money & 16.6 & 2.2 & 14.7 & 7.8 & 12.5 \\
\hline Net foreign assets & 25.4 & -4.6 & 28.7 & -4.8 & 1.4 \\
\hline Net domestic assets & -8.8 & 6.9 & -14.0 & 12.5 & 11.1 \\
\hline Monetary survey & \multicolumn{5}{|c|}{ (In billions of Nepalese rupees) } \\
\hline Broad money & 277.3 & 300.4 & 346.7 & 395.3 & 466.5 \\
\hline Narrow money & 94.0 & 100.2 & 112.9 & 126.7 & 148.4 \\
\hline Quasi money 1/ & 183.3 & 200.2 & 233.8 & 268.6 & 318.1 \\
\hline Net foreign assets & 108.8 & 107.7 & 139.5 & 131.9 & 133.9 \\
\hline Net domestic assets & 168.5 & 192.7 & 207.1 & 263.4 & 332.6 \\
\hline Domestic credit $1 /$ & 246.0 & 280.2 & 325.8 & 364.9 & 439.0 \\
\hline Public sector & 60.3 & 70.5 & 78.7 & 87.8 & 111.3 \\
\hline Government 2/ & 57.4 & 63.9 & 74.1 & 82.7 & 106.2 \\
\hline Public enterprises & 2.9 & 6.6 & 4.6 & 5.1 & 5.1 \\
\hline Private sector $3 /$ & 185.7 & 209.7 & 247.1 & 277.1 & 327.6 \\
\hline \multirow[t]{2}{*}{ Other items, net } & -77.5 & -87.5 & -118.7 & -101.5 & -106.4 \\
\hline & \multicolumn{5}{|c|}{ (Annual percentage change) } \\
\hline Broad money & 12.8 & 8.3 & 15.4 & 14.0 & 18.0 \\
\hline Narrow money & 12.2 & 6.6 & 12.7 & 12.2 & 17.2 \\
\hline Quasi money & 13.1 & 9.2 & 16.7 & 14.9 & 18.4 \\
\hline Domestic credit & 9.8 & 13.9 & 16.3 & 12.0 & 20.3 \\
\hline Public sector & -1.6 & 16.8 & 11.7 & 11.6 & 26.7 \\
\hline Government 2/ & -1.8 & 11.3 & 16.0 & 11.6 & 28.4 \\
\hline \multirow[t]{2}{*}{ Private sector credit $3 /$} & 14.2 & 12.9 & 17.8 & 12.1 & 18.3 \\
\hline & \multicolumn{5}{|c|}{ (Change in percent of broad money at start of period) } \\
\hline Broad money & 12.8 & 8.3 & 15.4 & 14.0 & 18.0 \\
\hline Net foreign assets & 7.1 & -0.4 & 10.6 & -2.2 & 0.5 \\
\hline Net domestic assets & 5.7 & 8.7 & 4.8 & 16.2 & 17.5 \\
\hline Domestic credit & 9.0 & 12.3 & 15.2 & 11.3 & 18.7 \\
\hline Private sector & 9.4 & 8.7 & 12.4 & 8.6 & 12.8 \\
\hline \multicolumn{6}{|l|}{ Memorandum items: } \\
\hline Velocity of broad money & 1.94 & 1.96 & 1.86 & 1.82 & 1.70 \\
\hline Broad money multiplier & 2.94 & 3.11 & 3.13 & 3.31 & 3.47 \\
\hline
\end{tabular}

Sources: Data provided by the Nepalese authorities; and Fund staff estimates and projections.

$1 /$ Commercial bank data are subject to revisions due to reporting lags.

2/ Central Government, adjusted for local government deposits.

3/ Includes lending by the Agriculture Development Bank of Nepal (ABDN) since July 2006. Reflects loan write-off of Nrs. 16 billion during July to December 2006. 
Table 4. Nepal: Balance of Payments, 2005/06-20121/13

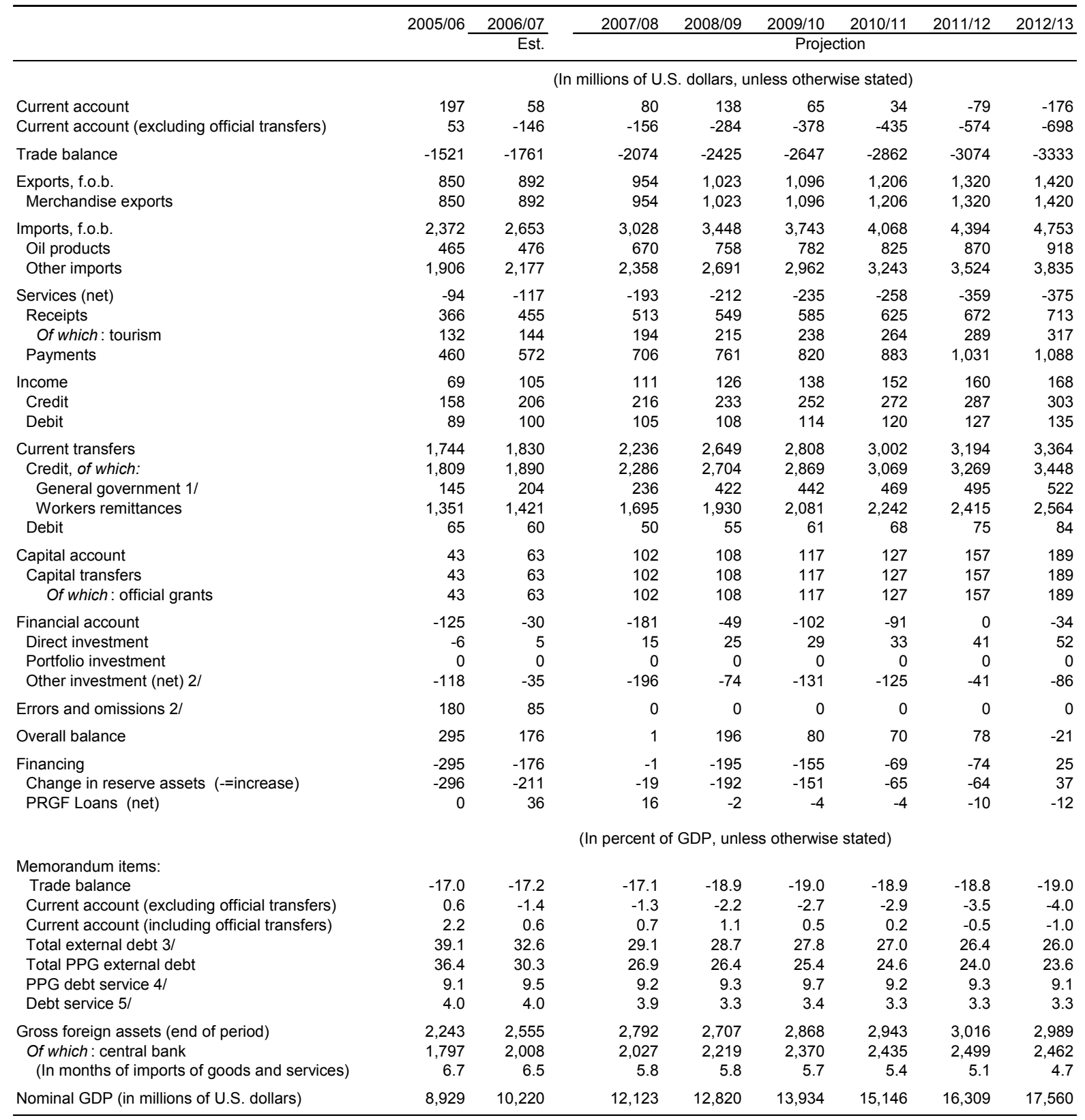

Sources: Data provided by the Nepalese authorities; and Fund staff estimates and projections.

1/ Includes estimated NGO transfers.

2/ Large other investments and errors and omissions reflect data weaknesses in capital account, unreported remittances and informal trade.

3/ Includes estimated private sector debt and short-term trade credits.

4/ As a ratio of exports of goods and services

5/ As a ratio of exports of goods and services, private transfer and income receipts; including debt service to the Fund. 
Nepal: Selected Economic Indicators, 2003/04-2007/08 1/

\begin{tabular}{|c|c|c|c|c|c|}
\hline & $2003 / 04$ & $2004 / 05$ & $2005 / 06$ & $\frac{2006 / 07}{\text { Est. }}$ & $\frac{2007 / 08}{\text { Proj. }}$ \\
\hline & \multicolumn{5}{|c|}{ (Percent change) } \\
\hline \multicolumn{6}{|l|}{ Output and prices } \\
\hline $\begin{array}{l}\text { Real GDP at market prices } \\
\mathrm{CPI} \text { (period average) }\end{array}$ & $\begin{array}{l}4.7 \\
4.0\end{array}$ & $\begin{array}{l}3.1 \\
4.5\end{array}$ & $\begin{array}{l}2.8 \\
8.0\end{array}$ & $\begin{array}{l}2.5 \\
6.4\end{array}$ & $\begin{array}{l}3.8 \\
6.5\end{array}$ \\
\hline Fiscal indicators & \multicolumn{5}{|c|}{ (In percent of GDP) } \\
\hline $\begin{array}{l}\text { Total revenue } \\
\text { Total expenditure } \\
\text { Current expenditure } \\
\text { Capital expenditure and net lending } \\
\text { Overall deficit after grants }\end{array}$ & $\begin{array}{r}11.3 \\
14.3 \\
10.3 \\
4.0 \\
0.9\end{array}$ & $\begin{array}{r}11.7 \\
14.9 \\
10.5 \\
4.4 \\
0.8\end{array}$ & $\begin{array}{r}10.9 \\
14.7 \\
10.4 \\
4.3 \\
1.6\end{array}$ & $\begin{array}{r}12.0 \\
15.7 \\
10.6 \\
5.1 \\
1.4\end{array}$ & $\begin{array}{r}13.5 \\
19.7 \\
13.4 \\
6.4 \\
3.6\end{array}$ \\
\hline Money and credit & \multicolumn{5}{|c|}{ (Percent change, end-of-period) } \\
\hline $\begin{array}{l}\text { Broad money } \\
\text { Domestic credit }\end{array}$ & $\begin{array}{r}12.8 \\
9.8\end{array}$ & $\begin{array}{r}8.3 \\
13.9\end{array}$ & $\begin{array}{l}15.4 \\
16.3\end{array}$ & $\begin{array}{l}14.0 \\
12.0\end{array}$ & $\begin{array}{l}18.0 \\
20.3\end{array}$ \\
\hline Balance of payments & \multicolumn{5}{|c|}{ (In millions of U.S. dollars) } \\
\hline $\begin{array}{l}\text { Current account balance (excluding official transfers) } \\
\text { In percent of GDP }\end{array}$ & $\begin{array}{r}59 \\
0.8\end{array}$ & $\begin{array}{r}-19 \\
-0.2\end{array}$ & $\begin{array}{l}53 \\
0.6\end{array}$ & $\begin{array}{r}-146 \\
-1.4\end{array}$ & $\begin{array}{r}-156 \\
-1.3\end{array}$ \\
\hline Exports, f.o.b. & 748 & 832 & 850 & 892 & 954 \\
\hline Imports, f.o.b. & 1801 & 2022 & 2372 & 2653 & 3028 \\
\hline Gross official reserves (end-of-period) & 1,457 & 1,501 & 1,797 & 2,008 & 2,027 \\
\hline External debt/GDP (in percent) 2/ & 46.1 & 39.9 & 39.1 & 32.6 & 31.4 \\
\hline Exchange rate (Nrs./U.S. dollar, end-of-period) & 74.5 & 70.7 & 74.4 & 65.2 & $\ldots$ \\
\hline
\end{tabular}

Sources: Data provided by the Nepalese authorities; and Fund staff estimates and projections.

1/ Fiscal year begins mid-July.

2/ Includes estimated short-term trade credits. 
INTERNATIONAL MONETARY FUND

NEPAL

Staff Report for the 2008 Article IV Consultation-Informational Annexes

Prepared by the Asia and Pacific Department

(In consultation with other departments)

May 2, 2008

Contents

Page

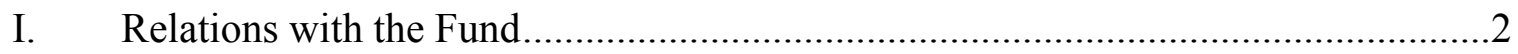

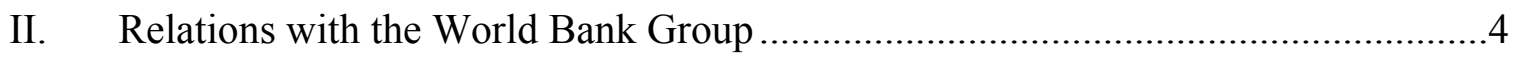

III. Relations with the Asian Development Bank......................................................11

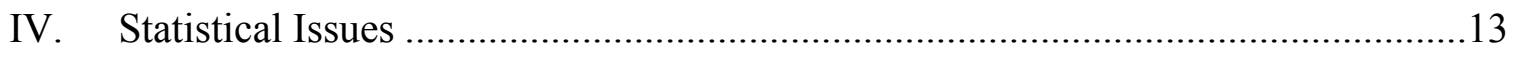


ANNEX I. NEPAL-FUND RELATIONS

(As of March 31, 2008)

I. Membership Status: Joined 9/06/61; Article VIII, Sections 2, 3, and 4 on May 30, 1994.

II. General Resources Account:

Quota

Fund holdings of currency

Reserve position in Fund

III. SDR Department:

Net cumulative allocation

Holdings

IV. Outstanding Purchases and Loans:

PRGF arrangements

SDR Million
71.30
71.31
0.00

SDR Million

8.10

5.71

SDR Million

49.90

Amount

Approved

(SDR Million)

49.90

33.57

26.11

\author{
Percent Quota \\ 100.00 \\ 100.02 \\ 0.00
}
Percent Allocation
100.00
70.48
Percent Quota
69.99

V. Financial Arrangements:

$\begin{array}{lcccc}\text { Type } & \begin{array}{c}\text { Approval } \\ \text { Date }\end{array} & \begin{array}{c}\text { Expiration } \\ \text { Date }\end{array} & \begin{array}{c}\text { Amount } \\ \text { Approved } \\ \text { (SDR Million) }\end{array} & \begin{array}{c}\text { Amount } \\ \text { Drawn } \\ \text { (SDR Million) }\end{array} \\ \text { PRGF } & 11 / 19 / 03 & 11 / 18 / 07 & 49.90 & 49.90 \\ \text { PRGF } & 10 / 05 / 92 & 10 / 04 / 95 & 33.57 & 16.79 \\ \text { SAF } & 10 / 14 / 87 & 10 / 13 / 90 & 26.11 & 26.11\end{array}$

VI. Projected Obligations to Fund (in millions of SDRs; based on existing use of resources and present holdings of SDRs):

\begin{tabular}{llllll} 
& \multicolumn{5}{c}{ Forthcoming } \\
\cline { 2 - 5 } & $\underline{2008}$ & $\underline{2009}$ & $\underline{2010}$ & $\underline{2011}$ & $\underline{2012}$ \\
Principal & & 1.43 & 2.85 & 2.85 & 6.77 \\
Charges/interest & $\underline{0.30}$ & $\underline{0.31}$ & $\underline{0.30}$ & $\underline{0.29}$ & $\underline{0.27}$ \\
Total & $\underline{0.30}$ & $\underline{\underline{1.74}}$ & $\underline{\underline{3.15}}$ & $\underline{\underline{3.14}}$ & $\underline{\underline{7.04}}$
\end{tabular}

\section{Exchange Rate Arrangement}

In February 1993, Nepal unified its exchange rate and eliminated the multiple currency practice associated with the previous dual exchange rate arrangement. In October 1997, the exchange arrangement of Nepal was reclassified as that pegged to a single currency unit from pegged to a currency composite. Currently, all merchandise imports (except for a few goods restricted for security or related reasons) are freely available through an open general license system, with foreign exchange provided through the banking system at the market exchange rate. Nepal's exchange system is free of restrictions on the making of payments and transfers for current international transactions. As of July 31, 2007, the exchange rate for the Nepalese rupee $(\mathrm{Nr})$ was US\$1=Nrs. 65.2.

\section{Safeguards Assessments}

A safeguards assessment of the Nepal Rastra Bank (NRB) was completed on September 2, 2002. The assessment concluded that substantial risks exist in the area of external and internal audits, and the internal control system of the NRB. A safeguards monitoring assessment was completed in October 2004. Staff findings and recommendations 
were reported in IMF Country Report No. 02/205. The NRB has made limited progress in the implementation of these recommendations, particularly with respect to the use of international standards in financial reporting and external audit and strengthening of internal controls in the NRB.

\section{2005 Article IV Consultation}

The Executive Board discussed the staff report for the 2005 Article IV consultation (IMF Country Report No. 06/44) on January 18, 2006. Until 2008, Nepal was on a 24-month consultation cycle, subject to the provisions of the July 15, 2002 decision on consultation cycles (Decision No. 129794-(02/76) as amended). It is proposed that the next Article IV consultation take place on the 12-month cycle.

\section{Technical Assistance Since 2001}

Department Purpose

MCM Accounting

Central bank and banking reform

Internal Audit

Monetary policy

Monetary operations

Strengthening central bank accounting and controls

Foreign exchange reserves management

Financial Sector Supervision

Liquidity management

FAD Implementation of a large tax payer unit

Review of tax policy and VAT administration

Tax and customs administration reform

Follow up on the LTO and customs administration reform

Tax/customs policy (fiscal reform)

Revenue Administration

Fiscal Transparency Legislation

LEG Redrafting of income tax laws

Income Tax Act

Banking Law

Fiscal Law

Fiscal Transparency

STA Multisector statistics

Balance of payments statistics

Producer prices statistics

Monetary statistics

National accounts

\section{Date}

10/04, 4/05, 9/05, 11/05, 7/06

$12 / 01-3 / 02$

10/04, 1/05, 4/05, 9/05, 1/07,

$7 / 07,11 / 05,7 / 06$

6/03

Continuous

$4 / 05$

$5 / 03,8 / 04,10 / 04,11 / 05,7 / 06$

$12 / 06,1 / 07,4 / 07$

$6 / 03$

$10 / 03$

$5 / 03$

$10 / 03,7 / 04,6 / 06,6 / 07$

$8 / 04,6 / 06,4 / 07$

$4 / 03$

$4 / 07$

$5 / 07$

$3 / 00,7 / 01,1 / 07$

$4 / 03$

$6 / 04,10 / 05$

$5 / 07$

$5 / 07$

$1 / 01,7 / 03$

$4 / 02,11 / 02,5 / 03,10 / 03,4 / 04$

$1 / 02,1 / 03,4 / 04,1 / 05$

$7 / 03$

$5 / 03,4 / 05,7 / 06$

\section{Resident Representative/Advisor}

Mr. Alexander Pitt has been the Resident Representative since August 2006. 


\section{ANNEX II. NEPAL-RELATIONS WITH THE WORLD BANK GROUP}

(As of April 30, 2008)

\section{Partnership in Nepal's Development Strategy}

Since the late 1990s, Nepal's poverty reduction agenda was held back by formidable challenges - that is, persistent political instability, the escalation of the Maoist insurgency and the global economic slowdown. Nevertheless, amidst the turbulence, a group of committed, reform-minded government officials and technocrats began implementing reforms in earnest in late 2001. These initiatives formed the basis for the first Immediate Action Plan (IAP) adopted by the Government in June 2002. For a while, reform efforts flourished in a number of areas, including the financial sector, public expenditures, the fight against corruption, infrastructure regulatory environment, and decentralized delivery of public services.

The reform group had been building on the successful experience with the IAP in moving the reform process forward. In developing the 2003 Poverty Reduction Strategy (PRS) formally sent to the World Bank and IMF in July 2003 - the scope of reform was broadened and a more integrated approach was adopted within a medium-term perspective. ${ }^{1}$ The PRS spells out specific development targets, foremost among which is the reduction of the overall poverty ratio from about 40 percent to 30 percent by the end of FY07. ${ }^{2}$ The PRS contains four pillars: (i) achieving sustainable and broad-based economic growth with an emphasis on the rural economy; (ii) accelerating human development through improved delivery of basic social services and economic infrastructure; (iii) ensuring social and economic inclusion of the poor, marginalized groups and less developed regions; and (iv) pursuing good governance to achieve better development results, and ensure social and economic justice. The technical elements of the government are trying to set their own development framework (Three-Year Interim Plan) and take back the development agenda from donors. Despite an extremely adverse political and economic environment, a PRS progress report by the National Planning Commission (NPC) prepared over a year ago notes that implementation of the PRS has been broadly satisfactory and measurable results are being achieved.

With the successful Constituent Assembly elections on April 10, 2008, the Bank is preparing policy note presentations on key issues to present to the new government.

\footnotetext{
${ }^{1}$ The PRS was discussed by the Boards in November 2003 following a joint staff assessment carried out by the two institutions. Subsequently, four PRS Progress Reports have been issued by the authorities.

${ }^{2}$ This target has nearly been met with recent analysis showing that the incidence of poverty in Nepal fell from 42 percent (1995-96) to 31 percent (2003-04), with urban areas experiencing greater reductions than rural areas in the depth and severity of poverty.
} 


\section{IMF-WORLD BANK COLLABORATION IN SPECIFIC AREAS}

\section{A. Areas in Which the Bank Leads and There is No Direct IMF Involvement}

The areas in which the Bank leads the policy dialogue and there is no direct IMF involvement are the social sectors, infrastructure, and environment. In the social sphere, the Bank provided technical assistance (TA) in conducting the Nepal Living Standards Survey II (NLSS II) during 2003/04 that updated household level information on trends in consumption, poverty, and their determinants. The TA also helped to strengthen the country's capacity to undertake regular household surveys that will facilitate poverty comparisons over time and to conduct social impact analyses. The NLSS II has been a key input into the three annual PRS progress reports, as well as the Bank's comprehensive poverty report-Nepal: Resilience Amidst Conflict-An Assessment of Poverty in Nepal, 1995-96 and 2003-04.

In education, the Bank and numerous other donors are actively supporting Nepal's well-formulated, ten-year primary education reform program. IDA along with Denmark, Finland, Norway, EC, ADB, UNICEF and the United Kingdom have established a joint financing arrangement whereby donor funds are pooled with public sector budgetary resources to support implementation of the program. IDA resources are provided through the Education for All project - which employs a sector-wide approach ("SWAp") — and the Second Higher Education.

The Bank has encouraged Nepal's decentralization efforts to achieve more effective delivery of public services and is playing a pivotal role in supporting the transfer of public schools to community management. The Community School Support Learning and Innovation Loan (LIL) aims to improve accountability of primary schools, build capacity of communities to manage schools and develop the roles of teachers, local officials, and education offices within the devolved framework.

In health, the Bank has been supporting the devolution of sub-health posts to local communities, and the development of a sector-wide reform strategy. A Health Sector Operation supports the program. Key reform priorities include addressing the problems of inadequate financing and inefficient public spending, weak institutional capacity, and overcentralized planning and management, weak delivery mechanisms and inequitable access to services. To support both human health and animal health, an Avian Influenza Control Project is under operation.

To support broad-based growth, the Bank supports investments in several key infrastructure sectors. The Power Development Project (PDP) is helping to develop the country's hydropower potential to meet electricity demand, improve access of rural areas to electricity services and promote private sector participation. The Telecommunications Sector Reform Project supports sectoral policy reforms in addition to the provision of greater rural access to telecommunications services through the introduction of a private operator. The Road Sector Development Project provides all-season road access in select hill districts.

To support rural development, the Nepal Irrigation and Water Resources Management Project aims to improve irrigated agriculture productivity and management of selected irrigation schemes, and enhance institutional capacity for integrated water resources 
management. At the same time, project finance is supporting decentralization to improve service delivery by promoting grassroots-driven, bottom-up planning and community-based management. The Rural Access Improvement and Decentralization Project (RAIDP) helps to improve governance and service delivery for rural infrastructure, while at the same time promoting agricultural and rural economic growth, and generating employment through direct project investments in rural transport infrastructure.

While many of the Bank's investment/sector operations mentioned above also support social inclusion, a more direct initiative in this area that received Bank support is the Poverty Alleviation Fund (PAF I and II). PAF channels resources to the poorest groups in rural communities by creating infrastructure, employment and income-generating opportunities. Bank financing through the PAF project supports implementation of the fund in 75 districts. In addition, the Bank - with DFID funding - is assisting Nepal in gaining a better understanding of the institutional underpinnings of caste, ethnic and gender-based social and economic exclusion and how these affect poverty outcomes and the options for policy and institutional reform through a completed social and gender analysis: Unequal Citizens: Gender, Caste and Ethnic Exclusion in Nepal.

In responding to environmental management, Bank assistance is focused on helping Nepal articulate an effective strategy for environmental conservation, management and capacity building. A Country Environmental Analysis was completed in FY07 and a study is underway on Adapting to Climate Change.

\section{B. Areas in Which the Bank Leads and Its Analysis Serves as Input into the IMF Program}

The Bank takes the lead in assisting Nepal with public expenditure analysis. The Bank's FY00 Public Expenditure Review (PER) provided analytical support for developing the strategy on public expenditure reform. Together with DfID, the Bank's intensive dialogue and technical assistance have been supporting the reforms, including the development of a credible Medium Term Expenditure Framework (MTEF). This framework has applied since FY04 to the prioritization of the development budget to ensure efficient budget allocations for priority projects. As Nepal implements its PRS, the MTEF will help the public sector translate the PRS priorities into fiscal realities.

Public expenditure analysis remains an integral part of the Bank's analytical and advisory (AAA) work program, consisting of (i) PER that focuses on evaluating the implementation of the MTEF; (ii) Public Finance Management (PFM) Review that examined the fiscal space for development activities and cross-sectoral allocation of public spending and service delivery; and (iii) Public Expenditure Financial Accountability (PEFA) assessment was recently completed and has established PFM benchmarks using the PEFA framework. The government is now seeking the continued cooperation of the WB and other development partners to implement the Action Plan to improve PFM.

To complement the economic analysis, studies on the public sector's framework for financial accountability and procurement - the Country Procurement Assessment Review (CPAR) and the Country Financial Accountability Assessment (CFAA) — were conducted jointly by the Bank and the Government. Additionally, in response to technical assistance and training needs on public expenditure management, decentralization and enhancement of financial 
accountability, the Bank is providing support through Institutional Development Fund (IDF) grants or other sources.

In the future, the Bank could provide additional support through development policy lending linked to (i) financing of a post-conflict program; (ii) supporting the transition to a more stable environment; and (iii) supporting reform implementation. In the meantime, to assist in the reform efforts the Economic Reform Technical Assistance (ERTA) Project is providing TA to help implement aspects of all the PRS pillars. The Bank's AAA program places emphasis on the need to address the challenges and bottlenecks to broad-based growth.

With respect to governance, in implementing both the 1998 and 2003 CASes, the Bank has consistently and firmly focused on helping Nepal address its fundamental constraint to development - poor governance. Albeit accompanied by intensive dialogue, the Bank's strong limited lending stance during FY99-FY02 (less than US\$25 million per year) may have provided some impetus to the wave of reforms initiated in the early 2000s. The public expenditure reform program which has benefited from the Bank's analytical work and policy dialogue is facing up to the challenge of improving not only efficiency but also governance. The program includes measures to fight corruption, ensure civil service accountability, and enhance transparency of public financial management and the procurement framework. Bank support for decentralization includes analytical assistance on the fiscal decentralization framework and promotion of the expanded roles of local bodies. Following the completion of the CPAR and CFAA, IDF grants are providing the means for strengthening relevant public sector institutions and implementing main policy recommendations. Nepal has been selected as a pilot country for the Bank's Governance and Anti-Corruption Plan (CGAC) and a Governance Assessment Note is under preparation.

\section{Areas of Shared Responsibility}

The Bank and the IMF - together with other external development partners-provided assistance during the preparation of the PRS and the subsequent PRS Progress Reports. In addressing the PRS pillar on good governance, the Bank and the IMF are assisting in the area of civil service reform through policy dialogue and TA towards ensuring an autonomous and professional civil service as well as fiscal sustainability.

The Bank and the IMF are partners in providing analytical support to Nepal on international trade, which is key to attaining broad-based growth. The Bank led the work with a Trade and Competitiveness Study which helped identify major constraints to further integrating the country into the multilateral trading system in a manner that is supportive of the PRS. The IMF contributed to the study by assessing macroeconomic policy and its potential impact on trade performance. In turn, the study is helping the IMF design its technical assistance program on tax policy, including import tariffs taking into account Nepal's WTO accession.

Financial sector reform is a fundamental area for Bank/IMF involvement. Since the mismanagement of key financial institutions was a major element of poor governance, progress in implementing financial sector reform has been the litmus test of political commitment to governance reform. The Bank and the IMF are helping to strengthen the central bank's authority and regulatory capacity, improve the financial health and restructure of the two largest state banks, and upgrade the legislative and institutional framework for the financial sector. Building on a comprehensive Financial Sector Study carried out in 2002, the 
Financial Sector Technical Assistance project supports (i) the restructuring and reengineering of the Central Bank; (ii) introduction of professional management teams into the two large ailing commercial banks (the first step toward eventual restructuring); (iii) capacity building towards enhanced credit information; and (iv) upgrading of staff training in financial institutions. The Financial Sector Restructuring project supports further strengthening of the Central Bank and deepening the reform process within the two banks. In FY05, a Legal Financial Review was completed providing a snapshot of the legal and judicial environment for financial sector growth and development. In addition, a recently completed study on Access to Finance helps to gain a better understanding of (i) the financial performance of the microfinance sector; and (ii) whether the current legal and regulatory framework is an obstacle to the sector's growth. Another study, Technology in Microfinance, is underway to examine how the use of technology in microfinance can improve access to financial services to the Nepalese majority. An Investment Climate Assessment is underway and will be completed in late FY09.

\section{WORLd BANK GROUP STRATEGY AND LENDING OPERATIONS}

The Country Assistance Strategy (CAS): In November 2003, a CAS was presented to the Bank's Board of Directors, which discussed the rationale for implementing a 'base case' lending program equivalent to approximately US\$190 million annually. Given the nature of the country's ongoing reforms, the CAS Progress Report (CAS PR) prepared in 2002 had already presented the justification for moving to a base case scenario that included implementing a programmatic approach to financial assistance. An Interim Strategy Note (ISN) was presented to the Board in February 2007 and a note on the implementation of the ISN was circulated in August 2007. A new CAS will be prepared and presented to the Board in late FY09.

The Lending Program: So far, in FY08, four projects (of which one is for additional financing) have been approved for US\$252.6 million and three more projects are scheduled to be presented to the Board on May 6 for another US\$127 million, bringing the total FY08 lending to US\$379.6 million.

Bank Assistance Program in Nepal: As of March 31, 2008, IDA's lending portfolio consisted of sixteen projects with a total commitment of US\$782.8 million and a total undisbursed balance of US\$583 million (Table II.1).

Economic and Sector Work: The 2003 Country Assistance Strategy (Report No. 26509-NEP, 11/24/2003) was discussed by the Bank's Board in November 2003. Recently completed economic and sector work includes Nepal Development Policy Review: Restarting Growth and Poverty Reduction (June 2004), Unequal Citizens: Gender, Caste and Ethnic Exclusion in Nepal (June 2005), Nepal Decentralized Organizations Study (March 2004), Urbanization and Service Delivery in the Context of Decentralization: A Review of the Issues for the Kathmandu Valley (December 2004), Legal Financial Review (February 2005), North South Transport Corridor Options (August 2004), Nepal: Resilience Amidst Conflict: An Assessment of Poverty in Nepal, 1995-96 and 2003-04 (June 2006) and Managing Public Finances for a New Nepal (June 2007). 
Table II.1. World Bank Operations

\begin{tabular}{clrr}
\multicolumn{3}{c}{ (as of March 31, 2008) } \\
\hline FY & Project & $\begin{array}{c}\text { IDA } \\
\text { (US\$mln) }\end{array}$ & Undisb. \\
\hline 2008 & PAF II & 100.00 & 100.00 \\
2008 & Irrigation \& Water Rural & 50.00 & 50.00 \\
2008 & Road Sector Development & 42.60 & 42.60 \\
2008 & Education For All Additional Financing & 60.00 & 60.00 \\
2007 & Second Higher Education & 60.00 & 60.00 \\
2007 & Avian Influenza Control & 18.20 & 17.00 \\
2005 & Education for All Project & 110.00 & 72.30 \\
2005 & NP. Economic Reform TA & 3.00 & 1.60 \\
2005 & Nepal Health Sector Program Project & 50.00 & 18.20 \\
2005 & Rural Access Improve. \& Decentralization & 32.00 & 27.30 \\
2004 & NP Fin Sector Restructuring (Phase II) & 75.50 & 20.50 \\
2004 & Poverty Alleviation Fund & 40.00 & 15.90 \\
2004 & Rural Water Supply \& Sanitation Project & 25.30 & 8.70 \\
2003 & NP Financial Sector Technical Assistance & 16.00 & 7.90 \\
2003 & POWER DEVELOPMENT PROJECT & 74.80 & 68.60 \\
2003 & Community School Support Project & 5.00 & 3.77 \\
2002 & NP: Telecommunications Sector Reform & 20.40 & 8.70 \\
& & 782.80 & 583.07
\end{tabular}

\section{A. Activities of the International Finance Corporation (IFC) in Nepal}

Investment Services: As of end January 2008, the IFC's outstanding balance portfolio in Nepal is US\$39.93 million in two power generation projects, one tourism project, and one leasing company. Given the security situation, opportunities for new investments had been limited. More recently, as the peace process continues and the security situation improves, IFC is considering new investment opportunities in cement, hydropower and the financial sector. In 2005, IFC launched the Global Trade Finance Program (GTFP) which offers confirming banks partial or full guarantees on issuing banks' payment risk. In FY07, IFC signed two Nepali Banks, Bank of Kathmandu and Nepal Industrial and Commercial Bank, to the Global Trade Finance Program (US\$2 million each). IFC is in discussion with Himalayan Bank for participation in the GTFP. The IFC is also considering equity investments with Bank of Kathmandu and Himalayan Bank.

\section{B. IFC Advisory Services}

Privatization/Corporate Advisory Services: IFC has initiated discussions with the GoN on providing advisory services for a possible privatization/restructuring of Nepal Airlines and Nepal Telecom. IFC's main delivery mechanism for technical assistance for small and medium enterprises (SMEs) in Nepal is through the Dhaka-based South Asia Enterprise Development Facility (IFC-SEDF). This facility - funded by IFC in partnership with Canada, Netherlands, Norway, the United Kingdom, Asian Development Bank, and the European Union-delivers TA programs to increase access for SMEs to financing and business 
development services, improve the business environment for SMEs and develop linkages with larger enterprises.

Access to Finance: IFC-SEDF has signed a Partner Financial Institution MOU with the Himalayan Bank and the Bank of Katmandu and hopes to sign another MOU with the NIC Bank very shortly. The MOUs outline specific programs to assist the banks with institutional capacity building that will help enhance the quality of service to the bank's SME clients. By comparing the FIs to best practice banks in this sector, the diagnostics provide a needs-gap analysis of the Banks' strengths, weaknesses, opportunities and threats within the overall structure of the bank. The road-map for future interventions is based on these findings. Diagnostic of NIC Bank is scheduled for mid-June. Future work will include a Credit Bureau Strengthening Project aimed at making the newly privatized Credit Bureaus commercially viable.

Future Advisory Services (AS) to the banks will include developing appropriate SME banking products and services and building their institutional capacity through training. These activities will involve assisting the Bank to transition to a more industrialized form of banking and would involve a cultural change in mindset from traditional corporate banking. AS will be provided to develop more standardized products, streamlined processes and for effective use of technologies to derive more cost-effective delivery channels. Targeted AS will be provided to assist the banks formulate a holistic SME strategy, including human resources policy, and implementing this strategy in an effective manner.

Business Enabling Environment: At the request of the Ministry of Industry, Commerce, and Supplies (MoICS), IFC-SEDF and FIAS jointly undertook a detailed review of the draft Special Economic Zone (SEZ) legislation in September 2006. This was followed by an Investment Climate Mini Diagnostic (February-March 2007) which uncovered constraints to investment in terms of excessively rigid labor regulations, inefficient customs administration, non-transparent and inconsistent tax administration, inappropriate and uncoordinated licensing and certification regimes, lack of inspections capacity, and barriers to exit.

The proposed SEZ regime presents an important opportunity for Nepal to offer a stable and efficient environment for investors to do business in the short term while building up the support for scaling up reforms to the national level through demonstration effects. FIAS and IFC-SEDF are currently developing a four year US\$6 million Nepal Investment Climate Reform Program (NICRP) - focused on helping the SEZs meet international best practice.

Questions on IDA may be referred to Ms. Paralkar (458-9050) or on the IFC to Mr. Paul Barbour (473-7349). 


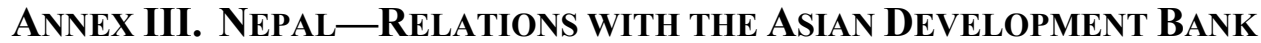

\section{Country Program}

As of 31 December 2007, cumulative lending to Nepal was $\$ 2.25$ billion, comprising 111 loans and six grant projects amounting to \$183.9 million. Sectors covered through AsDB loans and grants are agriculture and natural resources, education, energy, finance, industry and trade, law, economic management and public policy, transport and communication, and water supply, sanitation, and waste management. AsDB's total country program for Nepal in 2008 amounts to \$106.7 million-Education Sector Cluster Program (\$8 million, subprogram 2), Information and Communications Development Project (\$25 million), Power Sector Development Project I (\$30 million) and Local Governance and Community Development Support Program I (\$43.7 million).

Undisbursed funds of $\$ 588$ million represent 69 percent of the total portfolio amount as of 31 December 2007.

Loans and Grants by the Asian Development Bank, 1969-2007

(As of 31 December 2007)

\begin{tabular}{|c|c|c|c|c|c|c|c|c|}
\hline & 1968-2000 & 2001 & 2002 & 2003 & 2004 & 2005 & 2006 & 2007 \\
\hline & \multicolumn{8}{|c|}{ (In millions of U.S. dollars) } \\
\hline \multicolumn{9}{|c|}{ 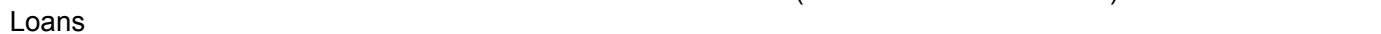 } \\
\hline Agriculture and natural resources & 656.23 & 0 & 0 & 20 & 70 & 0 & 0 & 0 \\
\hline Education & 61.1 & 19.6 & 30 & 0 & 20 & 0 & 30 & 0 \\
\hline Energy & 364.4 & 0 & 0 & 0 & 0 & 0 & 0 & 0 \\
\hline Finance & 7.3 & 0 & 0 & 0 & 0 & 0 & 56 & 0 \\
\hline Industry and trade & 129.18 & 0 & 0 & 0 & 0 & 0 & 0 & 0 \\
\hline Law, economic and public policy & & 30 & & 35 & 0 & 0 & 0 & 0 \\
\hline Transport and communication & 236.86 & 46 & 0 & 0 & 20 & 0 & 0 & 0 \\
\hline Water supply, sanitation and waste & & & & & & & & 0 \\
\hline management & 224 & 0 & 0 & 39 & 0 & 0 & 0 & \\
\hline Multisector & 127.06 & 0 & 30 & 0 & 0 & 0 & 0 & 0 \\
\hline \multicolumn{9}{|l|}{ Grant } \\
\hline Agriculture and natural resources & & & & & & & 18 & 0 \\
\hline Education & & & & & & & 2 & 0 \\
\hline Finance & & & & & & & 8.7 & 0 \\
\hline Transport and communication & & & & & & & 55.2 & 0 \\
\hline Multisector & & & & & & & & 100 \\
\hline Total grants & & & & & & & 83.9 & 100 \\
\hline Total approved (loan and grant) & $1,806.13$ & 95.6 & 60 & 94 & 110 & 0 & 169.9 & 100 \\
\hline Gross disbursements & $1,220.60$ & 57.3 & 28.2 & 33.5 & 22 & 43.7 & 108.0 & 102. \\
\hline \multicolumn{9}{|l|}{ Technical assistance } \\
\hline Total approved & 98.03 & 4.03 & 4.02 & 4.17 & 3.16 & 2.05 & 5.82 & 7.22 \\
\hline Gross disbursements & 54.1 & 5 & 3.9 & 4.17 & 4.2 & 3.6 & 2.04 & 4.6 \\
\hline
\end{tabular}

\section{Technical Assistance}

Since 1968, AsDB has provided Nepal with technical assistance in most sectors. As of 31 December 2007, ADB approved 270 technical assistance projects totaling \$127.8 million. There are currently 33 ongoing TAs, including 2 JFPR projects 


\section{Private Sector Operations}

- Developing a strong and dynamic private sector is essential to the long-term economic growth of Nepal. AsDB aims to strengthen the role of the private sector in Nepal through prudent investments in its infrastructure sector. The AsDB's public sector lending and technical assistance program have also been helping Nepal to create a more conducive policy and legal environment for private sector development. At the end of 2007, cumulative approvals for 4 private sector projects in Nepal amounted to $\$ 58.64$ million while ADB's outstanding exposure to non-sovereign projects totaled $\$ 24.4$ million, representing 1.4 percent of ADB's total non-sovereign portfolio.

- Currently AsDB is looking into the possibility of financing the proposed $750 \mathrm{MW}$ West Seti Hydropower project. 


\section{ANNEX IV. NEPAL-STATISTICAL ISSUES}

Economic and financial data are generally adequate for surveillance, with scope for improvement, in particular in the timeliness and coverage of fiscal data, and in balance of payments compilation of remittances, and official and private financial flows. Nepal provides core data to the Fund and releases data in government and central bank publications. It has been a participant in the General Data Dissemination System (GDDS) since May 2001. Metadata were initially posted on the Dissemination Standards Bulletin Board in May 2001 and last updated in January 2007. A multisector statistics mission visited Kathmandu in January 2001.

\section{Real Sector Statistics}

The Central Bureau of Statistics (CBS) compiles national accounts using the dated methodology of the $1968 S N A$. Key estimates include GDP by industry (in current and constant prices) and by expenditure categories (current prices), and gross national income and savings. There are shortcomings due to lack of comprehensive and regular data sources. The limited source data suffer from inconsistencies, lags in availability, and insufficient detail. There are also shortcomings in record keeping by agencies, and access to records is not timely due to processing lags. Reflecting source data problems, compilation methods rely heavily on fixed ratios derived from surveys or ad hoc assumptions - for example, household consumption expenditure estimates are based on extrapolations of the 1995/96 benchmark living standard survey. STA missions in April 2005 and July 2006 provided support to the development of quarterly national accounts (QNA) and the rebasing of the annual national accounts to 2000/01 from 1994/95. These missions and other developments are within the context of a broader Asian Development Bank (AsDB) project aimed at strengthening the national accounts. A STA expert is scheduled to provide further assistance with development of QNA later in 2008.

The consumer price index (CPI) offers limited coverage based on dated expenditure weights derived from a 1995/96 household expenditure survey. Coverage is limited to urban areas while the consumption basket refers to a subset of the population, excluding the upper and lower two income deciles; single person households; households with more than eight persons; and households obtaining more than 50 percent of their consumption from own production or less than 50 percent of their income in cash. The national index aggregates regional indices using population weights rather than recommended expenditure weights.

The wholesale price index (WPI) was developed by the Nepal Rastra Bank (NRB) and first published in July 2001. The weights for the WPI, based on 1999/2000 data, are derived using a commodity flow approach with prices related to the first commercial transaction point. CBS compilation methods need improvement to implement weekly or bi-weekly price collection; the number of price quotations should be increased; and procedures for adjusting for quality differences require implementation. The CBS, with STA assistance, is developing a monthly producer price index (PPI) series, to replace the manufacturing price index, which is based on unit values rather than actual transaction prices. The PPI is expected to 
more accurately measure industrial sector inflation and improve deflation in the national accounts..

\section{Government Finance Statistics}

A revised budget classification system, introduced in 1996/97 and subsequently refined, has substantially improved fiscal statistics, in particular the division between current and capital spending. However, fiscal data by functional and economic classification are provided on an irregular basis with varying degrees of coverage. In addition, large amounts are still allocated to the contingency account, and monthly reporting of development spending excludes amounts directly paid by donors. Moreover, a number of fees collected outside the budget and the operations of local governments are not reported in the annual budget.

More timely data on revenue and expenditure are needed for effective fiscal control. A financial management project is underway and a system of 'flash' reporting covering selected districts that account for the bulk of expenditure is being developed. Further improvement of fiscal data collected by the Financial Comptroller General's Office would permit the Ministry of Finance $(\mathrm{MoF})$ to monitor more effectively actual revenue collections and expenditures, and to provide assessments during the course of the fiscal year. Such improvements will require further computerization in MoF regional offices, as well as donor financing and additional TA.

Consolidated accounts for the public enterprise sector are not compiled on a regular basis, and financial reporting by many individual enterprises is subject to long delays. Fund staff has assisted the authorities in processing surveys of public enterprises.

Government finance statistics are regularly reported for publication in the Government Finance Statistics Yearbook, but not the International Finance Statistics.

\section{Monetary and Financial Statistics}

Monetary data provided to the Fund by the NRB have been subject to revisions with lags of up to 12 months, complicating program monitoring. Monetary and financial statistics are compiled under the methodology of the IMF's 1984 Guide to Monetary and Financial Statistics. To update the NRB's compilation methods to the framework of Monetary and Financial Statistics Manual, 2000 (MFSM), a 2008 STA mission recommended to (i) include development banks and finance companies in the institutional coverage of monthly monetary statistics ${ }^{1}$ and, based on this expanded coverage, compile a monthly broad money/depository corporations survey; (ii) adopt center of economic interest criteria for classifying residents and nonresidents and for distinguishing resident/nonresident positions of the financial institutions, instead of the currently used criteria based on citizenship and

\footnotetext{
${ }^{1}$ Data provided to the mission indicate that the ratio of deposits at development banks and finance companies relative to total deposits at deposit-taking institutions was approximately 13 percent at end-2006/2007.
} 
currency of denomination; (iii) adopt the principle of effective control for distinguishing between public and private nonfinancial corporations; (iv) ensure that the IMF-related accounts are fully reflected in the NRB's balance sheet in accordance with the IMF Finance Department's instructions; (v) value monetary gold, SDR holdings, securities, and holdings of shares/equities based on the end-period fair value/market price; (vi) incorporate accruals in the outstanding amount of financial asset or liability instead of maintaining them on separate accounts; (vii) monitor activities of other, smaller deposit-taking institutions (namely, Postal Savings Bank, Micro Credit Development Banks, Savings and Credit Cooperatives, Citizens' Investment Trust) and include them in the institutional coverage of broad money/depository corporations survey when their deposit-taking activities become more significant; (viii) use Statement of Assets and Liabilities (Form No. 1), instead of the more aggregated set of data currently used, as the basis for compiling monetary accounts for commercial banks, development banks and finance companies; and (ix) start regular monthly reporting of monetary data in the SRF format for the NRB (SRF-1SR) and other depository corporations (SRF-2SR) based on the compilation system agreed with the mission.

\section{External Sector Statistics}

The NRB compiles and disseminates balance of payments statistics in conformity with the fifth edition of the Balance of Payments Statistics Manuel (BPM5), but does not compile statistics on the international investment position. Nepal has benefited from five STA balance of payments missions since the multisector statistics mission of 2001. Staffing has been increased and in September 2003, the authorities began disseminating balance of payments in BPM5 format. Nevertheless, other STA recommendations have not yet been fully implemented and net errors and omissions remain large. Work is still underway to improve the estimation of workers' remittances and the source data for private capital flows, but further work is needed to improve the recording of oil transactions, grants, foreign direct investment, short-term inflows, and other private capital flows.

Trade data compiled separately by the NRB, the Customs Department, and the Trade Promotion Center (overseas trade only) exhibit discrepancies. Export and import price indices are not compiled.

Incomplete and conflicting data on government external grants and loans complicate the estimation of foreign financing. The NRB monitors cash disbursements and repayments, but most commodity aid and direct payment are excluded. MoF reporting is also incomplete and not timely. With technical assistance from the United Kingdom's DFID, a new database with comprehensive data on disbursements, repayments, and the stock of outstanding government debt has been developed and is currently being refined. However, reporting of direct external grants remains problematic. 


\section{Nepal-Table of Common Indicators Required for Surveillance}

(As of April 18, 2008)

\begin{tabular}{|c|c|c|c|c|c|}
\hline & $\begin{array}{c}\text { Date of } \\
\text { Latest } \\
\text { Observation }\end{array}$ & $\begin{array}{l}\text { Date } \\
\text { Received }\end{array}$ & $\begin{array}{c}\text { Frequency } \\
\text { of } \\
\text { Data }^{6}\end{array}$ & $\begin{array}{c}\text { Frequency } \\
\text { of } \\
\text { Reporting }^{6}\end{array}$ & $\begin{array}{c}\begin{array}{c}\text { Frequency } \\
\text { of }\end{array} \\
\text { Publication }\end{array}$ \\
\hline Exchange rates & Mar. 2008 & Apr. 2008 & $\mathrm{D}$ and $\mathrm{M}$ & $\mathrm{W}$ and $\mathrm{M}$ & $\mathrm{D}$ and $\mathrm{M}$ \\
\hline $\begin{array}{l}\text { International reserve assets and reserve } \\
\text { liabilities of the Monetary Authorities } 1\end{array}$ & Nov. 2007 & Feb. 2008 & W & W & M \\
\hline Reserve/base money & Nov. 2007 & Jan. 2008 & M & M & M \\
\hline Broad money & Nov. 2007 & Jan. 2008 & M & M & M \\
\hline Central bank balance sheet & Nov. 2007 & Jan. 2008 & M & M & M \\
\hline $\begin{array}{l}\text { Consolidated balance sheet of the banking } \\
\text { system }\end{array}$ & Nov. 2007 & Mar. 2008 & M & M & M \\
\hline Interest rates ${ }^{2}$ & Nov. 2007 & Jan. 2008 & $\mathrm{~W}$ and $\mathrm{M}$ & $\mathrm{W}$ and $\mathrm{M}$ & $\mathrm{W}$ and $\mathrm{M}$ \\
\hline Consumer price index & Jan. 2008 & Apr. 2008 & M & M & M \\
\hline $\begin{array}{l}\text { Revenue, expenditure, balance and composition } \\
\text { of financing }^{3}-\text { general government }{ }^{4}\end{array}$ & Jun. 2007 & Jul. 2007 & W & W & W \\
\hline $\begin{array}{l}\text { Stocks of central government and central } \\
\text { government-guaranteed debt } t^{5}\end{array}$ & $2004 / 05$ & Jun. 2006 & $A$ & A & A \\
\hline External current account balance & $2006 / 07$ & Jun. 2007 & Q/A & $\mathrm{Q} / \mathrm{A}$ & A \\
\hline Exports and imports of goods and services & $2006 / 07$ & Jun. 2007 & M & M & M \\
\hline GDP/GNP & 2007 & Jan. 2008 & A & A & A \\
\hline Gross external debt & $2004 / 05$ & Jun. 2007 & A & A & A \\
\hline
\end{tabular}

${ }^{1}$ Includes reserve assets pledged or otherwise encumbered as well as net derivative positions.

${ }^{2}$ Both market-based and officially determined, including discount rates, money market rates, rates on treasury bills, notes and bonds.

${ }^{3}$ Foreign, domestic bank, and domestic nonbank financing.

${ }^{4}$ The general government consists of the central government (budgetary funds, extra budgetary funds, and social security funds) and state and local governments.

${ }^{5}$ Including currency and maturity composition.

${ }^{6}$ Daily (D), weekly (W), monthly (M), quarterly (Q), annually (A), irregular (I); and not available (NA). 


\section{INTERNATIONAL MONETARY FUND}

NEPAL

\section{Joint IMF/World Bank Debt Sustainability Analysis}

Prepared by the Staffs of the World Bank and the International Monetary Fund

Approved by Steven Dunaway and Matthew Fisher (IMF) and Ernesto May and Carlos Braga (World Bank)

May 5, 2008

Public debt dynamics are assessed using the Low-Income Country Debt Sustainability Analysis (LIC-DSA) framework, which was jointly prepared by the IMF and the World Bank. The baseline macroeconomic scenario is broadly the same as in the previous DSA. The initial net present value of debt has improved compared to the previous DSA due to the appreciation of the Nepalese rupee and lower than projected loan disbursements in the interim. In view of the improved debt indicators, Nepal's external debt dynamics are assessed to be subject to a moderate risk of debt distress. This is a change from the previous DSA, which classified Nepal as at high risk of debt distress.

\section{A. Recent Debt Developments}

1. Nepal's public debt stock is estimated at 47 percent of GDP in 2007 (in nominal terms). Public external debt is estimated at US\$3.2 billion (33 percent of GDP) of which about US\$3 billion was owed to multilateral institutions, mostly IDA and the AsDB. Bilateral debt stock is estimated at about US\$270 million, with Japan as the largest creditor accounting for more than half of the bilateral debt. After remaining fairly constant at around 50 percent of GDP since 1995, the external debt stock dropped by about 17 percent during 2004-2007 as a result of relatively low external loan disbursements and the appreciation of the Nepalese rupee. The domestic debt stock accounts for around 14 percent of GDP and constitutes an increasing share of total public debt.

\section{B. Assumptions}

2. Baseline projections of public and publicly guaranteed (PPG) debt are based on the following key assumptions:

- $\quad$ Real sector: Real GDP growth is projected to rise gradually from 3.8 percent in $2007 / 08$ as the peace process takes hold and stabilize at 51/2 percent after 2010/11, in line with growth rates observed in the $1990 \mathrm{~s}$ - a period of relative stability - and supported by structural reforms and sound macroeconomic policies. In the longer 
term, Nepal's vast untapped hydropower potential is expected to contribute significantly to growth. The exchange rate is projected to depreciate against the dollar, in line with projected movements in the Indian rupee to which the Nepalese rupee is pegged. Inflation is assumed to decline from around 6.5 percent in 2007/08 to an average of about 5 percent in the medium term in line with projected inflation developments in India and as supply bottlenecks are gradually alleviated.

- $\quad$ Fiscal sector: The revenue-to-GDP ratio is projected at $13 \frac{1}{2}$ percent in 2007/08 and projected to average 14.3 percent in 2014-28 owing to gradual improvements in revenue mobilization. The expenditure-to-GDP ratio is projected around $191 \frac{1}{2}$ percent in 2007/08 and assumed to be maintained at this level thereafter. ${ }^{1}$ Official grants are assumed to average 3 percent of GDP in 2007/08-2012/13 as donors are expected to support the peace process; from 2013/14 onwards official grants are projected to decline as a share of GDP.

- External sector: Exports of goods and services are projected to grow at an average of about 8 percent over the projection period, supported by tourism and growth in partner countries. Imports of goods and services (in dollar terms) are expected to grow by an average of 11 percent in the medium term, fuelled by remittances and in line with economic activity. Import growth during 2013/14-2027/28 is assumed to average 6.6 percent. The current account balance is projected to deteriorate from a surplus of 0.9 percent of GDP in 2007/08 to a moderate deficit of 1.6 percent of GDP by $2027 / 28$ driven by the development needs, with remittances declining gradually as a share of GDP. New financing is assumed to rise from about US\$200 million in $2007 / 08$ to US $\$ 450$ million by $2012 / 13$; from $2013 / 14$ onwards official disbursements are expected to gradually decline as a share of GDP. The grant element of new borrowing is assumed to gradually decline during the projection period, with an average of 46 percent.

\section{Baseline}

\section{PPG External Debt}

3. A key feature of the LIC-DSA framework is that it compares debt burden indicators to indicative policy-based thresholds. The thresholds are based on the empirical finding that low-income countries with stronger policies and institutions tend to have a higher debt carrying capacity. Nepal is classified as a medium performer based on its three year average CPIA score during 2004-06. At end-2007, Nepal's NPV of public debt-toexports ratio is estimated at 148 percent (the relevant policy based indicative threshold is

\footnotetext{
${ }^{1}$ The projected increase in the fiscal spending in 2007/08 is driven mainly by pre-election and election spending, higher costs associated with clearing Nepal Oil Corporation's arrears, and increased donor flows.
} 
150 percent). The ratio is projected to fall to 87 percent by 2027/28. Other indicators remain below the policy-based indicative thresholds throughout the projection period. ${ }^{2}$

4. In the baseline scenario, debt burden ratios are projected to fall between $\mathbf{2 0 0 7 / 0 8}$ and 2027/28 (Table 1). The NPV of external public debt-to-GDP is projected to decline from 20 percent to around 12 percent; the NPV of external public debt-to-exports is projected to fall from 148 percent to 87 percent; and the external public debt service-to-exports ratio is projected to decline from 9 percent to 6 percent. $^{3}$

Nepal: Indicative External Debt Burden Indicators

\begin{tabular}{|c|c|c|c|}
\hline & $\begin{array}{l}\text { Indicative } \\
\text { Thresholds }\end{array}$ & $\begin{array}{c}\text { Nepal: } \\
2006 / 07\end{array}$ & $\begin{array}{c}\text { Nepal: } \\
\text { projected } \\
\text { average } \\
2007 / 08- \\
2027 / 28\end{array}$ \\
\hline \multicolumn{4}{|c|}{ NPV of debt, in percent of } \\
\hline Exports & 150 & 148 & 116 \\
\hline GDP & 40 & 22 & 15 \\
\hline Revenue & 250 & 163 & 114 \\
\hline \multicolumn{4}{|c|}{ Debt Service, in percent of } \\
\hline Exports & 20 & 11 & 7 \\
\hline Revenues & 30 & 12 & 6 \\
\hline
\end{tabular}

\section{Total Public Debt}

5. Domestic debt accounts for about 30 percent of total public debt at end-2007. For the baseline scenario, the NPV of public debt-to-GDP ratio declines from 35 percent at end $2007 / 08$ to 26 percent by 2027/28 (Table 4, Figure 2). Over the same period, the NPV of public debt to-revenue ratio falls from 216 percent to 157 percent, and the public debt service-to revenue ratio decreases from 17 percent to 12 percent.

\footnotetext{
${ }^{2}$ The baseline projections expect the current account, which has been historically a surplus in Nepal, to unwind gradually into a deficit, as spending and higher growth result in more imports of goods and services and the surge in remittances stabilizes. The average current account deficit over the projection period 2008-28 is a little over 1 percent of GDP relative to the historical average of a surplus current account of 3.4 percent. The results of the historical scenario, where the current account surplus of 3.4 percent of GDP continues into the projection period, suggests negative borrowing and thereby steady declines in debt. In view of this, debt is constrained to zero in 2018.

${ }^{3}$ Given the high concessionality of external debt, the debt service-to-exports ratio is low, and at levels similar or lower than to most HIPCs after full HIPC debt relief. The ratio reflects debt service on existing debt and debt service on projected disbursements.
} 


\section{Sensitivity Analysis}

6. Stress tests and alternative scenarios suggest vulnerability to shocks.

- $\quad$ Total public debt: A shock modeled as real GDP growth at historical average minus one standard deviations in 2009-10 results in the NPV of debt-to-GDP ratio increasing from 35 percent in 2008 to 41 percent in 2028; the NPV of Debt-toRevenues-and-Grants ratio increases from 215 to 250 percent; and the debt service to revenue ratio increases from 17 to 23 percent. This scenario illustrates the importance of the peace dividend as reflected in stronger real GDP growth. Alternative scenarios reveal vulnerabilities from maintaining the 2008 fiscal stance (primary balance), which could result in the NPV of debt-to-GDP ratio increasing from 35 in 2008 to 44 percent in 2028 .

- External debt: Bound tests indicate that the NPV of debt-to-export ratio is sensitive to shocks. Following a combined, half-standard deviation shock to export growth, GDP deflator, and net non-debt creating flows, the NPV of debt-to-exports ratio increases significantly, peaking at near 300 percent in 2010, and stays above the threshold for most of the projection period. Other bound tests (e.g. shocks to exports and non-debt creating flows) also cause the NPV of debt-to-exports to break the thresholds. These results are partly driven by Nepal's volatile export performance in the past decade. Shocks to other debt indicators such as the NPV of debt-to-GDP and debt service-to-revenue, result in trajectories below threshold values.

\section{E. Staff Assessment}

7. Based on the LIC-DSA, staffs conclude that Nepal's external debt dynamics are subject to a moderate risk of distress. Since the last DSA in 2007, the initial net present value of debt has improved due to the appreciation of the Nepalese rupee and lower than projected loan disbursements in the interim. In contrast to the previous DSA, the baseline scenario does not indicate a protracted breach of debt thresholds. In view of this, Nepal's external debt dynamics are assessed to be subject to a moderate risk of debt distress. This said, bound tests reflecting shocks to export growth and non-debt creating flows could result in protracted breach of the debt thresholds. The sensitivity analyses underscore the need to implement sound macroeconomic policies and reforms, including through raising the real GDP growth rate and achieving higher export growth. Stronger and more stable growth in 
exports contributing to higher GDP growth, combined with foreign financing at favorable terms - preferably through grants — would help Nepal make progress toward achieving its MDG targets while containing risks to debt sustainability. 


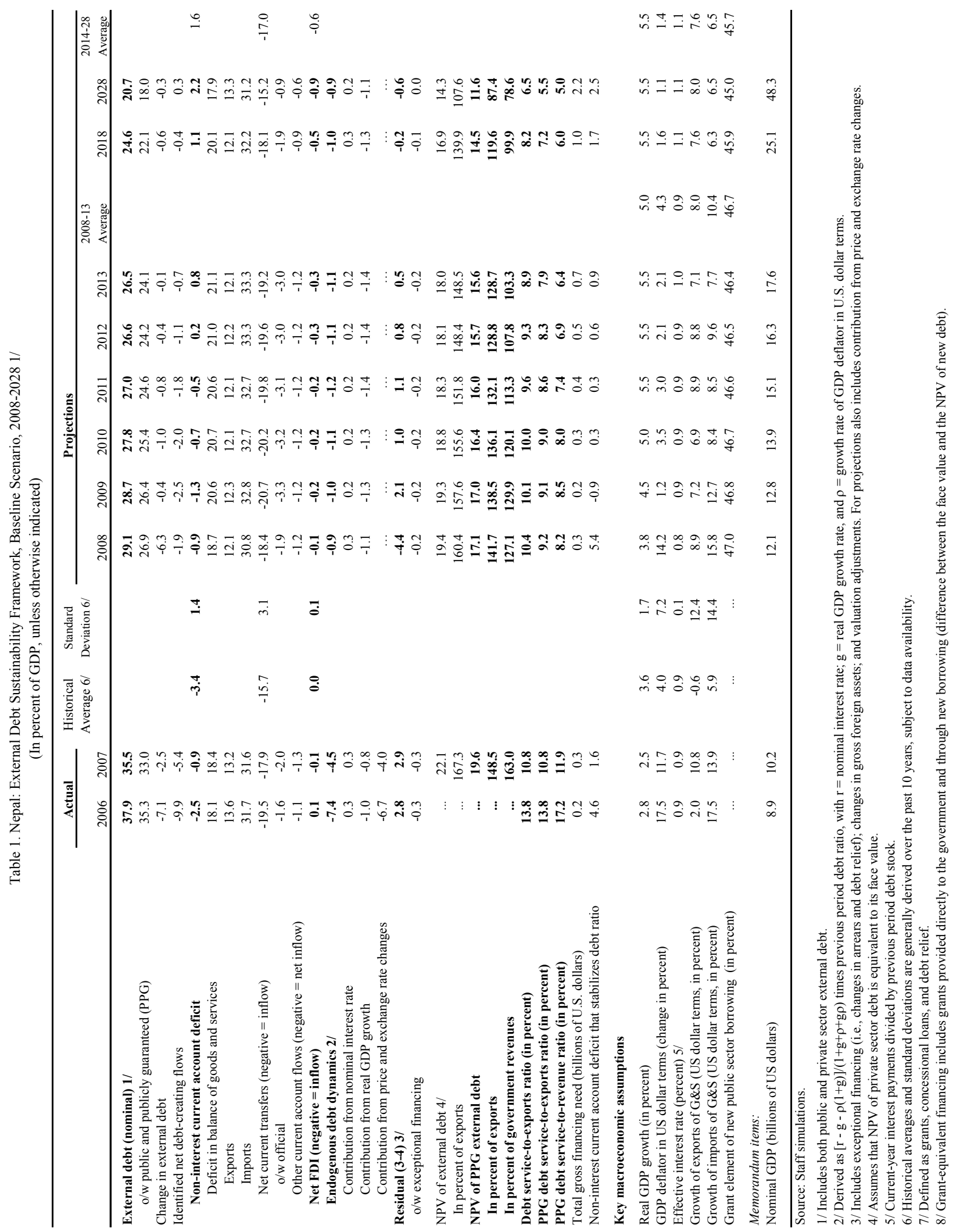


Table 2. Nepal: Sensitivity Analyses for Key Indicators of Public and Publicly Guaranteed External Debt, 2008-28

(In percent)

\begin{tabular}{|c|c|c|c|c|c|c|c|c|}
\hline & \multicolumn{8}{|c|}{ Projections } \\
\hline & 2008 & 2009 & 2010 & 2011 & 2012 & 2013 & 2018 & 2028 \\
\hline \multicolumn{9}{|c|}{ NPV of debt-to-GDP ratio } \\
\hline Baseline & 17 & 17 & 16 & 16 & 16 & 16 & 14 & 12 \\
\hline \multicolumn{9}{|l|}{ A. Alternative Scenarios } \\
\hline A1. Key variables at their historical averages in $2009-28$ 1/ & 17 & 16 & 14 & 13 & 11 & 9 & $\mathbf{0}$ & 0 \\
\hline A2. New public sector loans on less favorable terms in $2009-282 /$ & 17 & 18 & 17 & 18 & 18 & 18 & 19 & 19 \\
\hline \multicolumn{9}{|l|}{ B. Bound Tests } \\
\hline B1. Real GDP growth at historical average minus one standard deviation in 2009-10 & 17 & 17 & 17 & 17 & 17 & 17 & 15 & 12 \\
\hline B2. Export value growth at historical average minus one standard deviation in 2009-10 3/ & 17 & 18 & 20 & 19 & 19 & 19 & 17 & 13 \\
\hline B3. US dollar GDP deflator at historical average minus one standard deviation in 2009-10 & 17 & 18 & 18 & 18 & 18 & 17 & 16 & 13 \\
\hline B4. Net non-debt creating flows at historical average minus one standard deviation in 2009-10 4/ & 17 & 22 & 25 & 24 & 24 & 24 & 21 & 14 \\
\hline B5. Combination of B1-B4 using one-half standard deviation shocks & 17 & 22 & 29 & 28 & 27 & 27 & 23 & 16 \\
\hline B6. One-time 30 percent nominal depreciation relative to the baseline in 20095 / & 17 & 24 & 23 & 23 & 22 & 22 & 21 & 17 \\
\hline
\end{tabular}

\section{NPV of debt-to-exports ratio}

Baseline

$\begin{array}{rrrrrrrr}142 & 138 & 136 & 132 & 129 & 129 & \mathbf{1 2 0} & 87 \\ & & & & & & & \\ 142 & 129 & 117 & 104 & 87 & 72 & \mathbf{0} & 0 \\ 142 & 143 & 145 & 145 & 146 & 151 & \mathbf{1 5 9} & 143 \\ & & & & & & & \\ & & & & & & & \\ 142 & 138 & 136 & 132 & 129 & 129 & \mathbf{1 2 0} & 87 \\ 142 & 184 & 251 & 243 & 236 & 235 & \mathbf{2 1 3} & 144 \\ 142 & 138 & 136 & 132 & 129 & 129 & \mathbf{1 2 0} & 87 \\ 142 & 176 & 209 & 202 & 196 & 194 & \mathbf{1 7 1} & 106 \\ 142 & 204 & 291 & 281 & 272 & 269 & \mathbf{2 3 6} & 145 \\ 142 & 138 & 136 & 132 & 129 & 129 & \mathbf{1 2 0} & 87\end{array}$

A. Alternative Scenarios

A1. Key variables at their historical averages in 2009-28 1/

A2. New public sector loans on less favorable terms in 2009-28 2

B. Bound Tests

B1. Real GDP growth at historical average minus one standard deviation in 2009-10

B2. Export value growth at historical average minus one standard deviation in 2009-10 3/

B3. US dollar GDP deflator at historical average minus one standard deviation in 2009-10

B4. Net non-debt creating flows at historical average minus one standard deviation in 2009-10 4/

B5. Combination of B1-B4 using one-half standard deviation shocks

B6. One-time 30 percent nominal depreciation relative to the baseline in 2009 5/

NPV of debt-to-revenue ratio

Baseline

\section{A. Alternative Scenarios}

A1. Key variables at their historical averages in 2009-28 1/

A2. New public sector loans on less favorable terms in 2009-28 2/

\begin{tabular}{rrrrrrrr}
127 & 121 & 103 & 89 & 73 & 58 & $\mathbf{0}$ & 0 \\
127 & 134 & 128 & 125 & 122 & 121 & $\mathbf{1 3 3}$ & 129 \\
& & & & & & & \\
127 & 133 & 127 & 120 & 114 & 109 & $\mathbf{1 0 6}$ & 83 \\
127 & 140 & 146 & 138 & 130 & 124 & $\mathbf{1 1 7}$ & 86 \\
127 & 136 & 134 & 126 & 120 & 115 & $\mathbf{1 1 1}$ & 88 \\
127 & 166 & 185 & 173 & 164 & 155 & $\mathbf{1 4 3}$ & 96 \\
127 & 170 & 210 & 197 & 186 & 176 & $\mathbf{1 6 1}$ & 106 \\
127 & 185 & 171 & 161 & 153 & 147 & $\mathbf{1 4 2}$ & 112 \\
\hline
\end{tabular}

\section{B. Bound Tests}

B1. Real GDP growth at historical average minus one standard deviation in 2009-10

B2. Export value growth at historical average minus one standard deviation in 2009-10 3/

B3. US dollar GDP deflator at historical average minus one standard deviation in 2009-10

B4. Net non-debt creating flows at historical average minus one standard deviation in 2009-10 4/

B5. Combination of B1-B4 using one-half standard deviation shocks

B6. One-time 30 percent nominal depreciation relative to the baseline in 2009 5/

Source: Staff projections and simulations.

1/ Variables include real GDP growth, growth of GDP deflator (in U.S. dollar terms), non-interest current account in percent of GDP, and non-debt creating flows. Owing to the debt dynamics based on the historical period, the NPV of debt turns negative and is therefore set to zero.

$2 /$ Assumes that the interest rate on new borrowing is by 2 percentage points higher than in the baseline., while grace and maturity periods are the same as in the baseline

3/ Exports values are assumed to remain permanently at the lower level, but the current account as a share of GDP is assumed to return to its baseline level after the shock (implicitly assuming an offsetting adjustment in import levels).

4/ Includes official and private transfers and FDI.

5/ Depreciation is defined as percentage decline in dollar/local currency rate, such that it never exceeds 100 percent.

6/ Applies to all stress scenarios except for A2 (less favorable financing) in which the terms on all new financing are as specified in footnote 2. 





Table 4.Nepal: Sensitivity Analysis for Key Indicators of Public Debt 2008-2028

\begin{tabular}{|c|c|c|c|c|c|c|c|c|}
\hline & \multicolumn{8}{|c|}{ Projections } \\
\hline & 2008 & 2009 & 2010 & 2011 & 2012 & 2013 & 2018 & 2028 \\
\hline \multicolumn{9}{|c|}{ NPV of Debt-to-GDP Ratio } \\
\hline Baseline & 35 & 35 & 34 & 33 & 32 & 31 & 26 & 26 \\
\hline \multicolumn{9}{|l|}{ A. Alternative scenarios } \\
\hline A1. Real GDP growth and primary balance are at historical averages & 35 & 35 & 35 & 35 & 36 & 36 & 35 & 34 \\
\hline A2. Primary balance is unchanged from 2008 & 35 & 36 & 36 & 37 & 38 & 38 & 39 & 44 \\
\hline A3. Permanently lower GDP growth $1 /$ & 35 & 35 & 34 & 33 & 33 & 32 & 30 & 38 \\
\hline \multicolumn{9}{|l|}{ B. Bound tests } \\
\hline B1. Real GDP growth is at historical average minus one standard deviations in 2009-2010 & 35 & 36 & 37 & 37 & 37 & 36 & 35 & 41 \\
\hline B2. Primary balance is at historical average minus one standard deviations in $2009-2010$ & 35 & 36 & 37 & 36 & 35 & 33 & 28 & 28 \\
\hline B3. Combination of B1-B2 using one half standard deviation shocks & 35 & 36 & 37 & 36 & 34 & 33 & 27 & 25 \\
\hline B4. One-time 30 percent real depreciation in 2009 & 35 & 42 & 41 & 39 & 37 & 36 & 30 & 28 \\
\hline B5. 10 percent of GDP increase in other debt-creating flows in 2009 & 35 & 44 & 43 & 41 & 40 & 38 & 33 & 31 \\
\hline \multicolumn{9}{|c|}{ NPV of Debt-to-Revenue Ratio 2/ } \\
\hline Baseline & 216 & 213 & 203 & 192 & 182 & 171 & 157 & 161 \\
\hline \multicolumn{9}{|l|}{ A. Alternative scenarios } \\
\hline A1. Real GDP growth and primary balance are at historical averages & 214 & 213 & 207 & 204 & 202 & 200 & 202 & 197 \\
\hline A2. Primary balance is unchanged from 2008 & 215 & 218 & 216 & 214 & 214 & 214 & 232 & 266 \\
\hline A3. Permanently lower GDP growth $1 /$ & 215 & 212 & 203 & 193 & 185 & 176 & 175 & 230 \\
\hline \multicolumn{9}{|l|}{ B. Bound tests } \\
\hline B1. Real GDP growth is at historical average minus one standard deviations in 2009-2010 & 215 & 219 & 218 & 212 & 206 & 198 & 205 & 250 \\
\hline B2. Primary balance is at historical average minus one standard deviations in $2009-2010$ & 215 & 220 & 220 & 208 & 197 & 185 & 169 & 168 \\
\hline B3. Combination of B1-B2 using one half standard deviation shocks & 215 & 219 & 219 & 206 & 194 & 182 & 161 & 154 \\
\hline B4. One-time 30 percent real depreciation in 2009 & 215 & 258 & 242 & 227 & 213 & 199 & 176 & 170 \\
\hline B5. 10 percent of GDP increase in other debt-creating flows in 2009 & 215 & 268 & 253 & 239 & 226 & 213 & 195 & 189 \\
\hline
\end{tabular}

Debt Service-to-Revenue Ratio 2/

Baseline

A. Alternative scenarios

A1. Real GDP growth and primary balance are at historical averages

A2. Primary balance is unchanged from 2008

A3. Permanently lower GDP growth 1/

$\begin{array}{llllllll}17 & 17 & 17 & 17 & 17 & 17 & 16 & 16 \\ 17 & 16 & 18 & 19 & 19 & 20 & 20 & 26 \\ 17 & 17 & 16 & 16 & 15 & 14 & 15 & 20\end{array}$

B. Bound tests

B1. Real GDP growth is at historical average minus one standard deviations in 2009-2010

B2. Primary balance is at historical average minus one standard deviations in 2009-2010

B3. Combination of B1-B2 using one half standard deviation shocks

B4. One-time 30 percent real depreciation in 2009

B5. 10 percent of GDP increase in other debt-creating flows in 2009

$\begin{array}{llllllll}17 & 17 & 18 & 18 & 17 & 17 & 17 & 23 \\ 17 & 16 & 19 & 20 & 16 & 15 & 13 & 14 \\ 17 & 17 & 18 & 19 & 16 & 14 & 13 & 12 \\ 17 & 17 & 17 & 16 & 15 & 14 & 13 & 14 \\ 17 & 16 & 35 & 23 & 18 & 16 & 15 & 17\end{array}$

Sources: Country authorities; and Fund staff estimates and projections.

1/ Assumes that real GDP growth is at baseline minus one standard deviation divided by the square root of 20 (i.e., the length of the projection period).

2 / Revenues are defined inclusive of grants. 
Figure 1. Nepal: Indicators of Public and Publicly Guaranteed External Debt Under Alternative Scenarios, 2008-2028
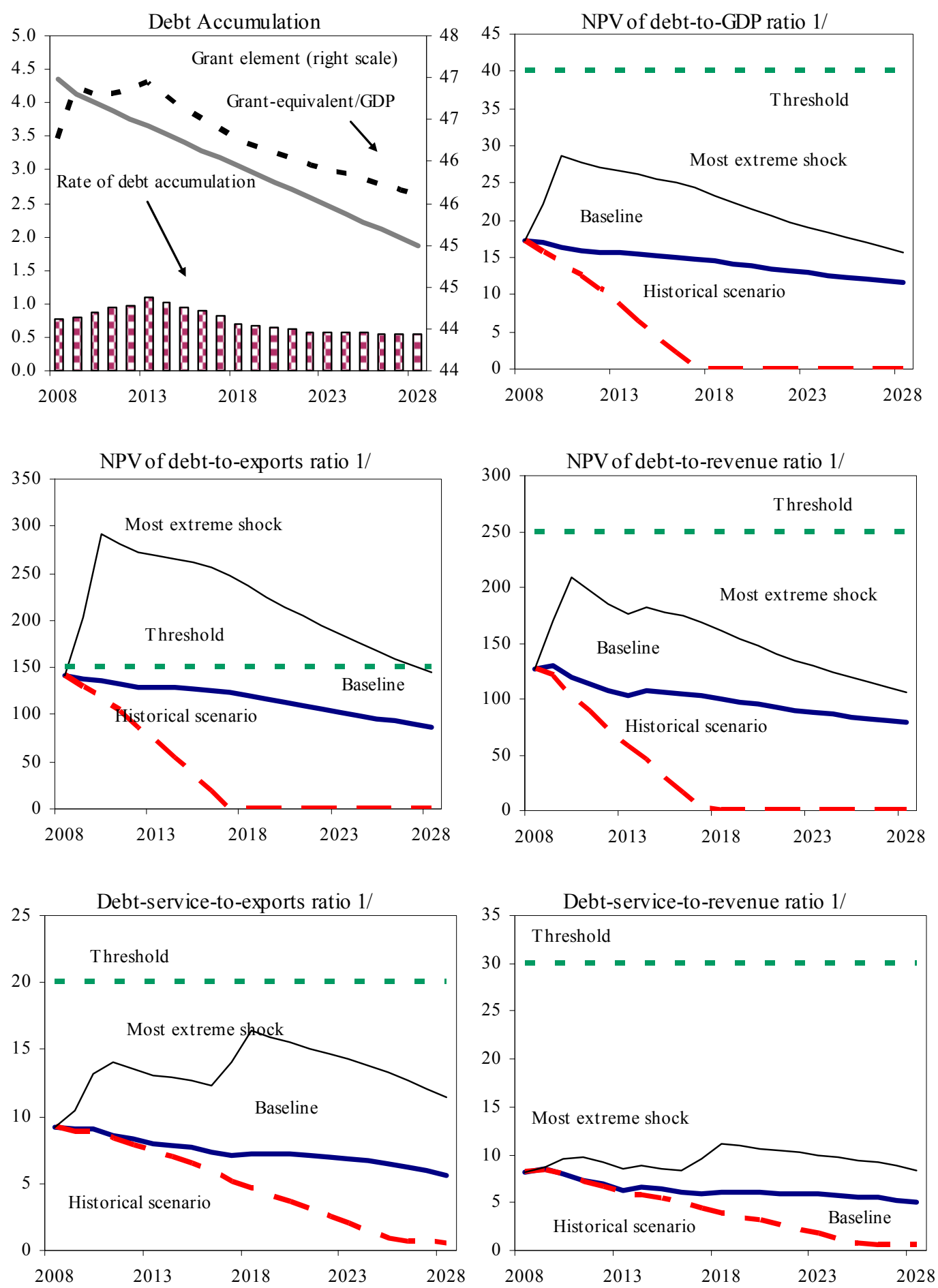

Source: Staff projections and simulations.

1/ Owing to the debt dynamics resulting from using historical averages, which cause the NPV of debt to become negative in part of the projection period, the debt indicators as sociated with a negative NPV of debt are set to zero. 
Figure 2. Nepal: Indicators of Public Debt Under Alternative Scenarios, 2008-2028 1/
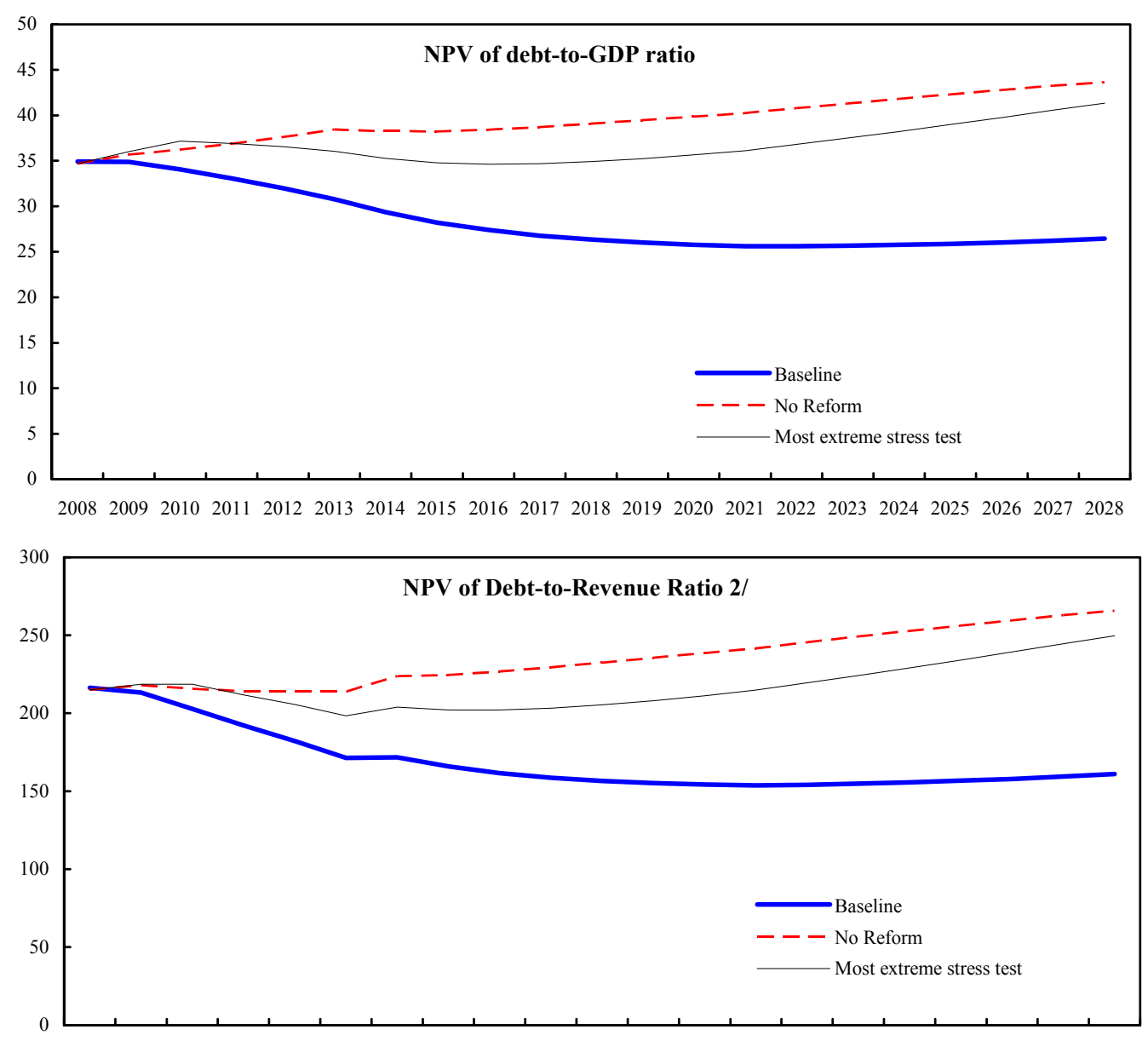

200820092010201120122013201420152016201720182019202020212022202320242025202620272028

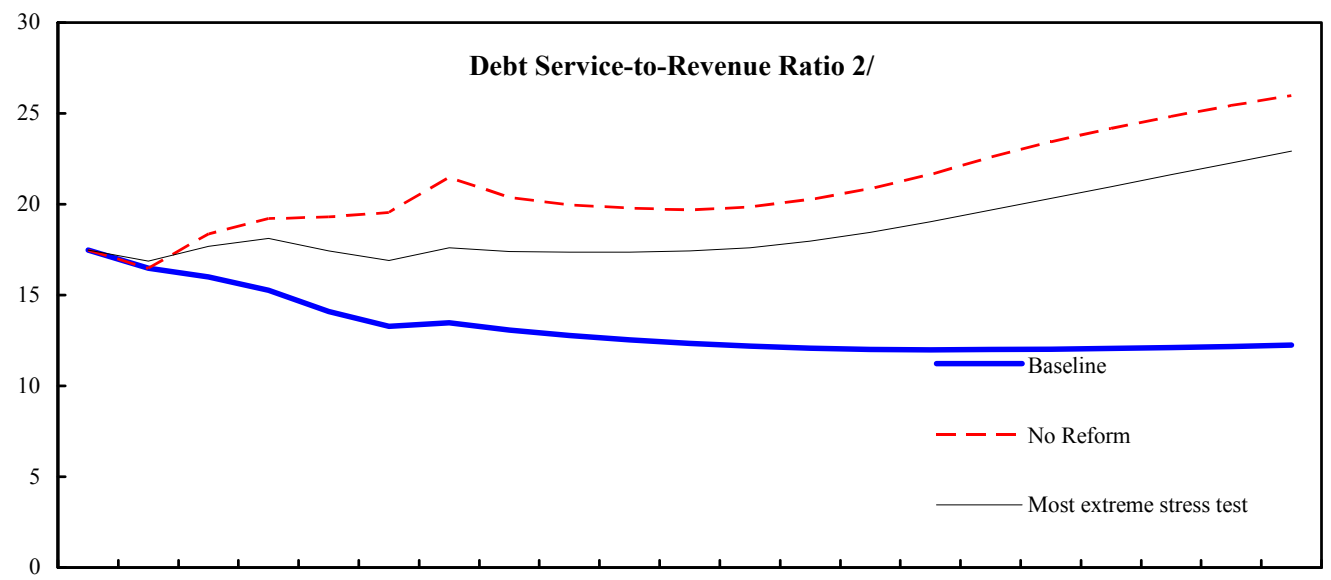

200820092010201120122013201420152016201720182019202020212022202320242025202620272028

Source: Staff projections and simulations.

1/ Most extreme stress test is test that yields highest ratio in 2018.

2/ Revenue including grants. 
Public Information Notice (PIN) No. 08/59

FOR IMMEDIATE RELEASE

May 27, 2008
International Monetary Fund $70019^{\text {th }}$ Street, NW

Washington, D. C. 20431 USA

\section{IMF Executive Board Concludes 2008 Article IV Consultation with Nepal}

On May 16, 2008, the Executive Board of the International Monetary Fund (IMF) concluded the Article IV consultation with Nepal. ${ }^{10}$

\section{Background}

Years of protracted political turmoil and conflict have retarded Nepal's economic growth. Per capita GDP has barely risen in the last decade and the country remains one of the poorest in the world. However, Nepal is now undergoing a major political transition. The next step in this process, the writing of a new constitution, will be carried out by the Constituent Assembly emerging from the elections held on April 10, 2008. Despite some pre-election violence, these elections were considered largely free and fair by international observers.

Despite civil conflict and political upheavals, macroeconomic performance under the Poverty Reduction and Growth Facility (PRGF)-supported program that ended last November has been stable: growth has been maintained, albeit at relatively low levels; the peg to the Indian rupee has helped keep inflation below 8 percent during the program period; the budget stance has been cautious; and foreign exchange reserves have doubled since 2002, boosted by a strong inflow of remittances.

\footnotetext{
${ }^{10}$ Under Article IV of the IMF's Articles of Agreement, the IMF holds bilateral discussions with members, usually every year. A staff team visits the country, collects economic and financial information, and discusses with officials the country's economic developments and policies. On return to headquarters, the staff prepares a report, which forms the basis for discussion by the Executive Board. At the conclusion of the discussion, the Managing Director, as Chairman of the Board, summarizes the views of Executive Directors, and this summary is transmitted to the country's authorities.
} 
The macroeconomic outlook for $2007 / 08^{11}$ remains stable. The agricultural recovery, a favorable service sector performance, and a significant increase in tourist arrivals could boost real GDP growth to $3 \frac{1}{2}-4$ percent in $2007 / 08$. Anchored by the exchange rate peg, inflation is projected to remain at around $61 / 2$ percent to 7 percent. On the external side, rising oil imports and stagnant exports have led to a further deterioration in the trade deficit, but this will be more than offset by higher workers' remittances. Despite a strong revenue performance, the budget deficit could rise this year to about $3 \frac{1}{2}$ percent of GDP, reflecting in part the one-off costs of the elections and the clearance of most of the state oil company's arrears. However, the company continues to accumulate sizable losses as high crude prices are only partially reflected in domestic prices for petroleum products.

While the macroeconomic performance has been stable, progress on structural reforms has been held back by the fragile political circumstances. In particular, little progress has been made to address institutional weaknesses in the financial sector and public financial management.

Vulnerabilities in Nepal's financial sector remain. Loose monetary conditions have led to negative real interest rates, rapid and potentially destabilizing stock market and property price increases, and some capital flight to India. Credit growth has been high, with aggressive lending by many private banks pushing their credit-to-deposit ratios to levels above 100 percent. Other vulnerabilities include weak supervisory capability and regulatory compliance, and stalled reforms of the two large public banks.

Limited progress has been made in addressing Nepal's structural weaknesses in tax administration and public financial management. Overall, the accounting, auditing, and reporting of public sector operations remain inadequate. The budget coverage is confined to only the central budget with limited information on quasi-fiscal activities, internal control procedures are not fully effective, and the management of spending is weak.

Looking ahead, Nepal's growth prospects depend most importantly on a peaceful political transition. Steady but low growth could continue in the near term. However, insecurity, violence in the Terai region, input supply disruptions, and structural barriers continue to discourage investment, limit exports, and hamper transition to a higher growth path. With Nepal located between two of the fastest growing economies in the world, an easing of these constraints, steady progress on the political front, and the development of Nepal's vast untapped hydropower resources could lift growth to levels of $5-51 / 2$ percent over the medium term.

\footnotetext{
${ }^{11}$ Fiscal year begins mid-July.
} 


\section{Executive Board Assessment}

Executive Directors commended the Nepalese authorities for maintaining budget discipline and macroeconomic stability over the past several years despite civil conflict and major political upheavals. Inflation has remained stable, public debt pressures have lessened, and foreign exchange reserves have grown significantly owing to strong worker remittance inflows. At the same time, economic growth has been slow.

Directors welcomed the recent successful conclusion of the election for the Constituent Assembly. They emphasized that Nepal is now at a critical juncture, and that continued stability is a key condition for allowing the current political transformation to result in higher, broad-based economic growth. Prerequisites for faster growth-in addition to improving infrastructure and reducing supply disruptions-include maintaining budget discipline and ensuring the soundness of the banking sector.

Directors noted that increased spending in some areas to improve the provision of public goods and address the legacy of the civil conflict should be balanced carefully against the need to keep domestic borrowing at sustainable levels. Further improvements in revenue collection will remain a priority, as will continued efforts by the authorities to secure external grants and concessional assistance. Directors considered that a key short-run fiscal priority will be to limit-and eventually eliminate-the losses of the Nepal Oil Corporation. They suggested that the authorities consider introducing an automatic pricing mechanism for petroleum products, which would depoliticize price setting.

While acknowledging recent efforts to manage liquidity through open market operations, Directors encouraged the authorities to pursue a more active monetary policy. They considered that a bias toward liquidity had led to negative real interest rates, rapid credit growth, potentially destabilizing asset price increases, and some capital flight, suggesting that some monetary tightening is in order. Directors called for further improvements in liquidity management and forecasting, and for the separation of the formulation and execution of monetary policy from public debt management.

Directors agreed that the pegging of Nepal's currency to the Indian rupee has served the country well given its extensive commercial ties to India, and that maintaining the peg in the near term will provide a credible nominal anchor and support Nepal's macroeconomic stability and development. With the overall balance of payments in surplus and the reserve position strong and stable, Directors saw little sign of exchange rate misalignment. However, a widening productivity gap with India could, over time, present exchange rate management challenges.

Directors urged the authorities to give renewed impetus to strengthening financial sector supervision and regulatory enforcement to maintain stability in the face of rapid banking sector growth. They looked forward to parliamentary approval of the Banking and Financial Institutions Act, which should further strengthen the regulatory framework, but stressed that 
significant improvements are needed in enforcement. The application of stricter licensing requirements will be an important signal of the authorities' willingness to tighten enforcement going forward. Directors called for a clearer strategy for completing the restructuring and commercialization of the two large public banks.

Public Information Notices (PINs) form part of the IMF's efforts to promote transparency of the IMF's views and analysis of economic developments and policies. With the consent of the country (or countries) concerned, PINs are issued after Executive Board discussions of Article IV consultations with member countries, of its surveillance of developments at the regional level, of post-program monitoring, and of ex post assessments of member countries with longer-term program engagements. PINs are also issued after Executive Board discussions of general policy matters, unless otherwise decided by the Executive Board in a particular case. 
Nepal: Selected Economic Indicators, 2003/04-2007/08 1/

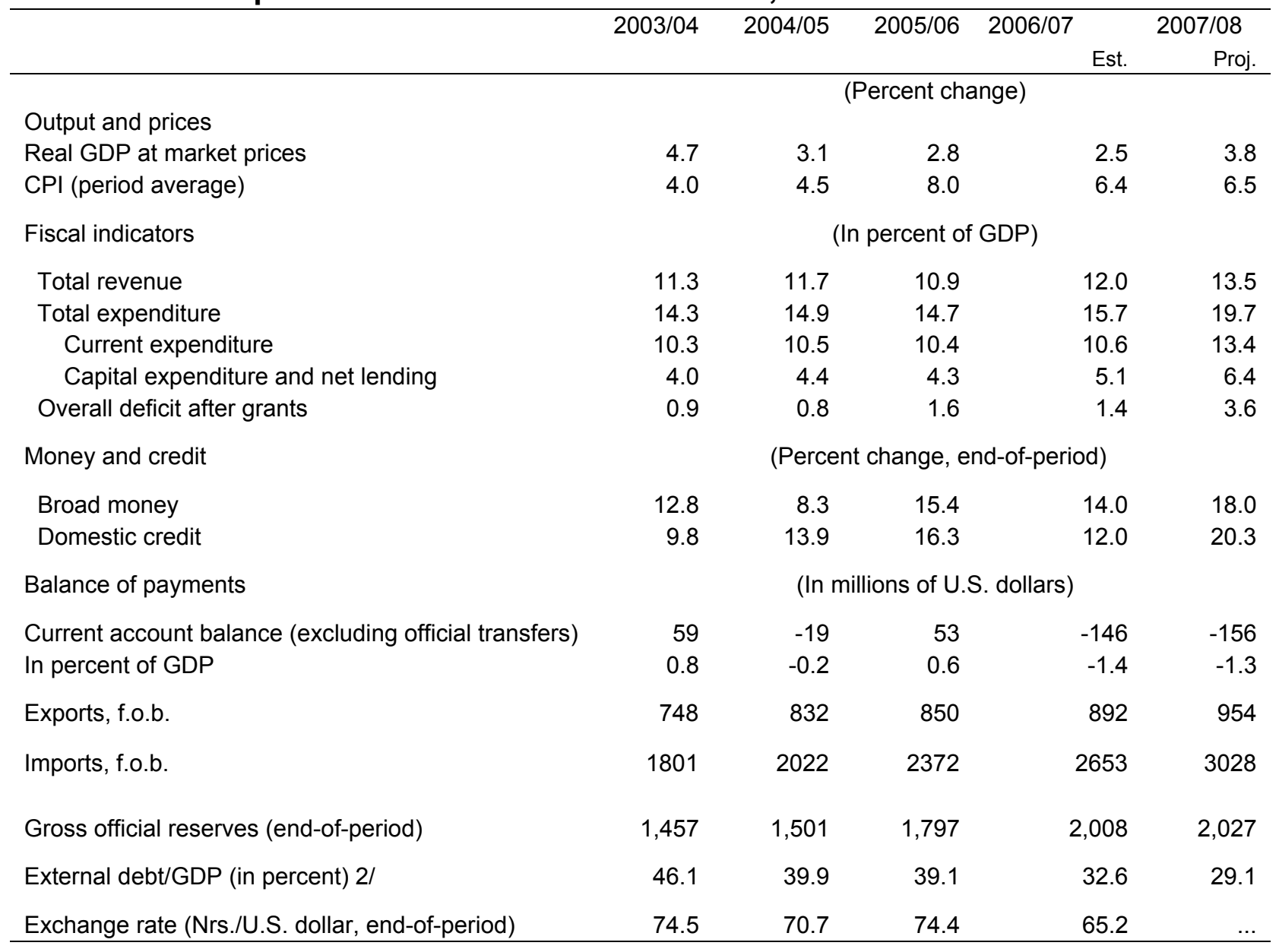

Sources: Data provided by the Nepalese authorities; and IMF staff estimates and projections.

1/ Fiscal year begins mid-July.

2/ Includes estimated short-term trade credits. 


\section{Statement by Perry Warjiyo, Executive Director for Nepal and Sushil Mathema, Senior Advisor to Executive Director \\ May 16, 2008}

1. On behalf of the Nepalese authorities, we wish to express our sincere gratitude and appreciation to Mr. Brian Aitken and his able team for the fruitful dialogue during the Article IV Consultation held in Kathmandu on March 1-14, 2008. The authorities also find the staff reports a fair and balanced reflection of the discussions and are in broad agreement with the thrust of staff's appraisal.

2. The macroeconomic performance of Nepalese economy since the fifth and final review of the three-year PRGF-supported program on November 9, 2007 has remained stable. The growth momentum has been maintained with considerable level of both internal and external stability. Going forward, with an election internationally acknowledged as free and fair on April 10, 2008, Nepal has now entered into a new phase of peace and democracy, which is expected to result in greater macroeconomic stability and strengthen growth prospects. The continuation of the Fund program will further cement the success of these challenging political and economic transitions.

\section{Recent Political Developments}

3. On April 10, 2008, Nepal successfully held the Constituent Assembly (CA) election. The historic People's Movement of April 2006 ended the decade-long civil conflict. The CA election was a part of comprehensive peace agreement (CPA) reached among the seven-party alliance (SPA), in which the Maoist party has emerged as the largest party in the CA, with a simple majority. With this, one phase of political transition in Nepal has ended and the second phase has begun.

4. The CA elections have paved the way for the drafting of a new constitution. The political parties are making concerted efforts to reach an understanding to form a new government. It will take place following the first meeting of CA, slated within 21 days of the final announcement of the CA election results. The political parties have expressed their commitment to peace process and stressed the need for political consensus going forward. Furthermore, they are united in stressing the need for accelerating economic growth through improving the investment climate and initiating the necessary reforms.

\section{Macroeconomic Developments}

5. Despite the difficult political situation, Nepal managed to maintain stable macroeconomic conditions. Under the PRGF-supported program, annual economic growth averaged 3.4 percent. The growth in real GDP decelerated somewhat to 2.5 percent in 2006/07 compared to 2.8 percent in 2005/06. The slowdown was largely on account of adverse weather conditions, though a number of impediments relating to the political transition also constrained the growth.

6. The fiscal discipline, prudent monetary policy and, on top of that, the exchange rate peg helped to keep inflation at a moderate level. Consumer price-based inflation remained at a 
moderate level of 5.5 percent on average during the last five years. Inflation rates accelerated to 8 percent in 2005/06 and 6.4 percent in 2006/07 on account of the rise in energy prices and food prices.

7. Nepal's overall balance of payments (BOP) remained in surplus. The performance of merchandise exports has been less than satisfactory, mainly due to the removal of the multi-fiber agreement in 2005, poor labor relations, electricity shortages and infrastructure bottlenecks. The main driving factor behind the surplus was the elevated level of workers' remittances. In recent months, the growth in remittances accelerated further. As a result, Nepal's international reserves remained at the comfortable level. As of mid-March 2008, the accumulation of official international reserves stood at US\$ 2.2 billion, sufficient to cover 7.1 months' imports of goods and services.

\section{Macroeconomic Outlook}

8. Going forward, the authorities expect a higher rate of economic growth in 2007/08 and beyond. They believe the growth will be on the upper end of the staff's projection of 3.5-4 percent in 2007/08 compared to a growth of 2.5 percent in 2006/07. Notwithstanding weaker performance of merchandise exports and in the manufacturing sector, a satisfactory rate of growth in agriculture, an encouraging increase in tourist arrivals and some improvements in services sector underpin the growth outlook for 2007/08. Improvements in the investment climate and a continuation of structural reforms are expected to pave the way for more robust economic performance over the medium term.

9. Although risks to the inflation outlook exist, the authorities expect inflation to stabilize at around 7 percent in 2007/08. As in other countries, inflationary pressures emanate from higher energy, commodities and food prices. Of these, the greatest impact on headline inflation is likely to be the result of an overdue adjustment in oil prices. The authorities also note that the exchange rate peg plays a crucial role in anchoring prices in Nepal.

10. On the external front, the trade deficit is expected to widen with the higher growth of merchandise imports relative to exports. However, workers' remittances are expected to sustain the recent growth of 28 percent. This is likely to more than offset the trade deficit, leading to a modest surplus in the BOP.

\section{Fiscal Policy}

11. The Nepalese authorities continue to adopt fiscal discipline as they have shown during the PRGF program period. The net fiscal deficit remained at a lower level of 1.4 percent of GDP in 2006/07, on account of a pick up in revenue growth and a controlled expansion in government spending. The net domestic financing of budget deficit was lower at 0.9 percent of GDP in 2006/07. The government finance data as of May 2, 2008 showed a significant amount of cumulative cash balances maintained by the government with the NRB. As the revenue is showing an encouraging growth of 25.3 percent, the government's domestic borrowing is expected to remain within the budgeted limit, ensuring macroeconomic stability. 
12. Going forward, the authorities concur with the staff that maintaining fiscal discipline is likely to be a key policy issue in the face of rising public expectations. The threat to fiscal imbalance may arise from the growing public aspirations and the increasing demand for public expenditure on rehabilitation, relief measures and reconstruction of infrastructures. The significant risk to the fiscal accounts also comes from the persistent losses from Nepal Oil Corporation (NOC). The authorities had made an attempt to recoup the losses in recently by adjusting in oil prices upwards. However, the proposed increase was aborted in the face of strong public protest. In the current fiscal year alone, the government extended loans of 4 billion rupees to NOC to help maintain the domestic supply of petroleum products. The reform in oil sector remains a key policy challenge.

\section{Monetary and Exchange Rate Policy}

13. The Nepalese authorities concur with staff's assessment that the level of Nepalese real exchange rate is in line with fundamentals, thus supporting the external stability. In particular, given the specific nature of Nepalese workers abroad, they note that it is paramount to take into account the worker remittances in judging the current account norm for assessing the real exchange rate. The public debt-to-GDP ratio has also dropped significantly in recent years, contributing further to external stability. The ratio declined from 61.7 percent in 2002/03 to 43.9 percent in 2006/07. Likewise, total foreign debt has fallen from 45.4 percent of GDP in 2002/03 to 30.1 percent in 2006/07. As pointed out in the staff report, limited foreign borrowing and the nominal appreciation of Nepalese rupee against the U.S. dollar contributed to a significant drop in the public debt.

14. The authorities believe that the exchange rate peg has been an anchor that has contributed significantly in sustaining macroeconomic stability in Nepal. With the continued appreciation of Indian Currency (IC) vis-à-vis U.S. dollar, the nominal appreciation of Nepalese currency (NC) against US dollar has attracted public attention over the past year. The authorities have taken note of the staff's views in the selected issue paper that this is not the appropriate time to change the level and the regime of exchange rate. They are also of the view that risks to macroeconomic stability outweigh any potential benefits from a regime change.

15. With the exchange rate peg, the authorities concur with the staff on the need to maintain monetary policy discipline. Nonetheless, they would like to make a number of points with regard to staff's analysis. It is true that monetary growth has been in excess of what was initially projected. With the establishment of new banks, commercial banks in Nepal have expanded their activities in a more competitive environment. As some these commercial banks were recently established, there is an uneven distribution of liquidity. Given the political transition and fragile financial situation, a cautious monetary policy stance has been put in place. As stated in the staff report, the NRB intervened in the case of margin lending for investment in share market by the financial institutions. On January 22, 2008, the NRB issued a directive to banks and financial institutions to manage margin lending in an effective manner, which has ensured an orderly development in the stock market. The current thrust of monetary policy has also been to facilitate the orderly development of the financial sector. 
16. The NRB is also focusing on open market operations to manage the liquidity of the system. Open market instruments such as outright sale auctions, outright purchase auctions, repo auctions and reverse repo auctions are being used for this purpose. The liquidity monitoring and forecasting framework (LMFF) based on the weekly balance sheet of the NRB is employed to guide the open market operations. Besides this, the authorities are monitoring the banking sector liquidity on a daily basis and necessary interventions are being made accordingly. The authorities are committed to take appropriate policy actions to modulate the liquidity.

\section{Structural Reforms}

17. Our authorities are also of the view that continuation of structural reforms and maintaining financial sector stability are the keys in accelerating economic growth and thereby in helping alleviate poverty. A number of structural reforms relating to government finances, public enterprises and the financial sector were introduced during the recently-concluded PRGF program period. The establishment of a large tax office (LTO), wide area network (WAN) between headquarters and regional customs offices and expansion of the ASYCUDA system are some examples of fiscal sector reforms. In addition, a new custom act was enacted in September 2007, which includes a variety of broader reforms such as the implementation of an improved valuation system according to GATT principles, provision and permission for offsite declaration and clearance, declaration before the arrival of goods, provision of import return on re-export, special provision for Special Economic Zone (SEZ), post clearance audit, and risk-based audit.

18. The authorities have made a number of commendable efforts to increase fiscal transparency and accountability in the program period. The major steps taken by the government to improve transparency were the creation of CIAA (Commission for Investigation of Abuse of Authority), a National Vigilance Centre (NVC) to enforce accountability of politicians and bureaucrats, published guidance material for tax payers and organized public hearings in the tax and customs administrations, reclassification of expenditures into recurrent and capital, formulation and implementation of budget in line with MTEF, the publication of annual and midterm review of the budget and the publication of financial performance of public enterprises.

19. The authorities have also taken a number of measures aimed at maintaining financial sector stability in the face of the growth in the number of banks and financial institutions in recent years. The NRB doubled the minimum paid-up capital required for the establishment of new banks and financial institutions in April 2007. Similarly, a number of measures relating to fit and proper test for promoters, board of directors and chief executive officers of banks and financial institutions have been issued. With a view to remove distortions created by the system of crosslending of shares by the financial institutions, the NRB has issued a directive asking all the banks and financial institutions to divest promoter shares in other banks and financial institutions by mid-July 2008. As a measure to enforce regulatory capital, the NRB has issued recently a directive relating to prompt corrective actions to be effective from October 16, 2008. The Cabinet has already approved a revised draft of the Banks and Financial Institutions Act (BAFIA), incorporating 25 core principles of bank supervision, clear guidelines for mergers and acquisitions, and procedures for voluntary and involuntary liquidation. As a step forward to move to a Basel II framework by July 2008, the NRB has announced the parallel implementation of Basel II for the current fiscal year, and a trial reporting under the new system has been initiated. 
20. On bank restructuring, the authorities have resorted to operational and financial restructuring the two largest public banks under a World Bank FSRP. During the five-year restructuring period in both banks, substantial progress has been achieved. The banks have registered operational profits, a significant proportion of the NPAs have been reduced and 80 percent of the banks' operations are now computerized and incorporate a more modern approach. The authorities are of the opinion that the restructuring process should be continued further for an additional three years at the minimum, and that this process will be carried out by local professional bankers under the control of the NRB with concurrence from the World Bank.

21. In an effort to stem the losses of the NOC, the authorities made upward revisions in the price of petroleum products twice in the year. In the wake of the continuous rise in global oil prices, the authorities feel that the adjustment is still inadequate. Given that the country is passing through a political transition and the issue of energy price is politically sensitive, the authorities are considering a different approaches that allows gradual but steady price adjustments be made by introducing an automatic pricing mechanism, and will seek the private sector's participation both in the importation and distribution of oil.

\section{Conclusion}

22. Nepal's macroeconomic performance remains stable. The authorities acknowledge the important role played by the recently-concluded PRGF program in maintaining macroeconomic stability even under difficult political conditions. They are committed to safeguarding macroeconomic stability. As Nepal is in a critical juncture in its history, our authorities continue to solicit the support from the donor community to take the country forward to the path of sustainable peace and stable economic growth. A successor to the PRGF program would play another key role in anchoring the overall macroeconomic policy going forward. The authorities would like to thank the Executive Board and staff for their continued support and constructive advice.

23. Finally, we are pleased to inform the Board that the Nepalese authorities have consented to the publication of the staff report. 